\title{
BIRD USE IN A RESTORED RIPARIAN CORRIDOR, SOUTHWEST MONTANA ${ }^{1}$
}

\author{
R. Prodgers and N. Kohler ${ }^{2}$
}

\begin{abstract}
One century after mine waste left $32 \mathrm{~km}$-long Silver Bow Creek and its floodplain contaminated with acidic heavy metals, the State of Montana reclaimed it. While limited bird use occurred before remediation, large and varied populations quickly repopulated. Three of the most important habitats are open water, wetlands, and tall shrubs, but nearby habitats and land uses are also important. Migrations set the vernal monthly trends.

Bird data were summarized over 1.5 decades for four five-mile subareas, which are sets of habitats, not replicates. Sampling followed the Region 1 Forest Service monitoring procedure with fewer environmental descriptors. Twenty stations per subarea were sampled from March-June, which took about four hours per session starting just after dawn. Data analysis focused on bird abundance and diversity,

- March bird use is indicative of winter residents. Migratory birds swell the April census, which roughly doubles in May and June.

- Species compositions within subareas are weakly similar even for proximate years. This presages weak temporal trends.

- $\quad$ Birds quickly colonize fresh revegetation with no convincing trend in bird counting during the ensuing decade. Assigning birds to trophic levels likewise evidenced no decade-scale temporal trends.

- Analyzing bird use in the two main habitats, fluvial tall shrubs and wetlands, bird counts again revealed no temporal trends. In conjunction with low similarities, this indicates relatively steady abundance with variable composition.

- $\quad$ Species diversity (richness and evenness of relative abundance) increased over time beginning at about six years in wetlands and eight years in the fluvialtall- shrub type. Time keys for vegetational development.

- While most species' needs can be met by numerous habitat combinations, habitat specialists demonstrate convincing temporal trends in relation to specific vegetational development. The willow flycatcher and marsh wren require midseral to mature vegetation. Spotted sandpipers decline as gravelly shorelines fill with plants.
\end{abstract}

Key Words: Restored bird habitats, temporal trends, species diversity, trophic levels, revegetation, vegetational development, habitat specialists.

${ }^{1}$ Oral presentation at the 2019 National Meeting of the American Society of Mining and Reclamation, Big Sky, MT. Welcome back to Montana: The Land of Reclamation Pioneers, June 3-7, 2019. Published by ASMR, 1305 Weathervane Dr., Champaign, IL 61821.

${ }^{2}$ Richard A. Prodgers (presenter), plant ecologist, Bighorn Environmental Sciences, Dillon, MT 59725. Nate Kohler, ornithologist, Bighorn Environmental Sciences, Deer Lodge, MT 59722.

DOI: http://dx.doi.org/10.21000/JASMR19020001 


\section{SETTING AND INTRODUCTION}

The setting is the riparian corridor of Silver Bow Creek (SBC), a riparian Superfund site near Butte in southwest Montana (Fig. 1) with climate corresponding to USDA Plant Hardiness Zone 4a. This work was conducted near $46^{\circ} 0^{\prime} 23^{\prime \prime} \mathrm{N}, 112^{\circ} 42^{\prime} 48^{\prime \prime} \mathrm{W}$. Most of the 20-mile-long riparian zone receives an average of 12.5 inches $(32 \mathrm{~cm})$ of annual precipitation. May and June are typically the wettest months. The upper reaches of SBC run about $22 \mathrm{cfs}\left(0.6 \mathrm{~m}^{3} / \mathrm{s}\right)$ in summer and winter and about twice that during spring runoff with episodic high flows that, within the timeframe of this project, peaked at $250 \mathrm{cfs}\left(7.0 \mathrm{~m}^{3} / \mathrm{s}\right)$ in June 2011 . The lower reaches, newer and less analyzed for bird monitoring, have about $50 \mathrm{cfs}\left(1.4 \mathrm{~m}^{3} / \mathrm{s}\right)$ base flow with a recent high of 700 cfs $\left(19.8 \mathrm{~m}^{3} / \mathrm{s}\right)$ also in June 2011. Pre-mining habitat was a mix of graminoids with patches or strings of tall shrubs, mainly willows. Cottonwoods and aspen were rare near the creek due to beaver browsing.

Mining impacts to the upper reaches began in the 1860 s with the creek becoming a favorite waste receptacle. Butte boomed as a mining town with mines, smelters, and all that goes with them right in town. Due to several large floods at the turn of the $20^{\text {th }}$ century, Butte mine waste covered the floodplain, leaving a mosaic of barren (phytotoxic) tailings, acid- and metal-tolerant grasses (redtop [Agrostis stolonifera] and tufted hairgrass [Deschampsia cespitosa]) growing on moist mine waste, and some other plant communities rooted in clean dirt beneath a veneer of acidic heavy-metal tailings. The creek received partially treated sewage with nutrients promoting metaltolerant grasses along the streambank.

The contaminated riparian corridor was declared a Superfund site in 1983. From 1999 through 2014, about 6.1 million cubic yards $\left(4.7 \mathrm{MM} \mathrm{m}^{3}\right.$ ) of mine waste and contaminated dirt were removed and transported to a downstream repository. Remediation relocated the stream, brought the floodplain to grade with clean fill that was amended as needed, and revegetated the floodplain, mainly through seeding and secondarily by transplanting shrubs and wetland herbs.

The restorative element of revegetation provided additional contaminant removal in places and a wider array of native seeds and more woody transplants to provide physical structure for birds and other wildlife. The Montana Natural Resource Damages Program (NRDP) initiated bird inventories in Subarea 1 (SA 1) of the Streamside Tailings Operable Unit (SSTOU) in late winter 2005. A final bird sampling for the entire project is scheduled for SA 3 in 2019. 
Journal American Society of Mining and Reclamation, 2019 Vol.8, No.2

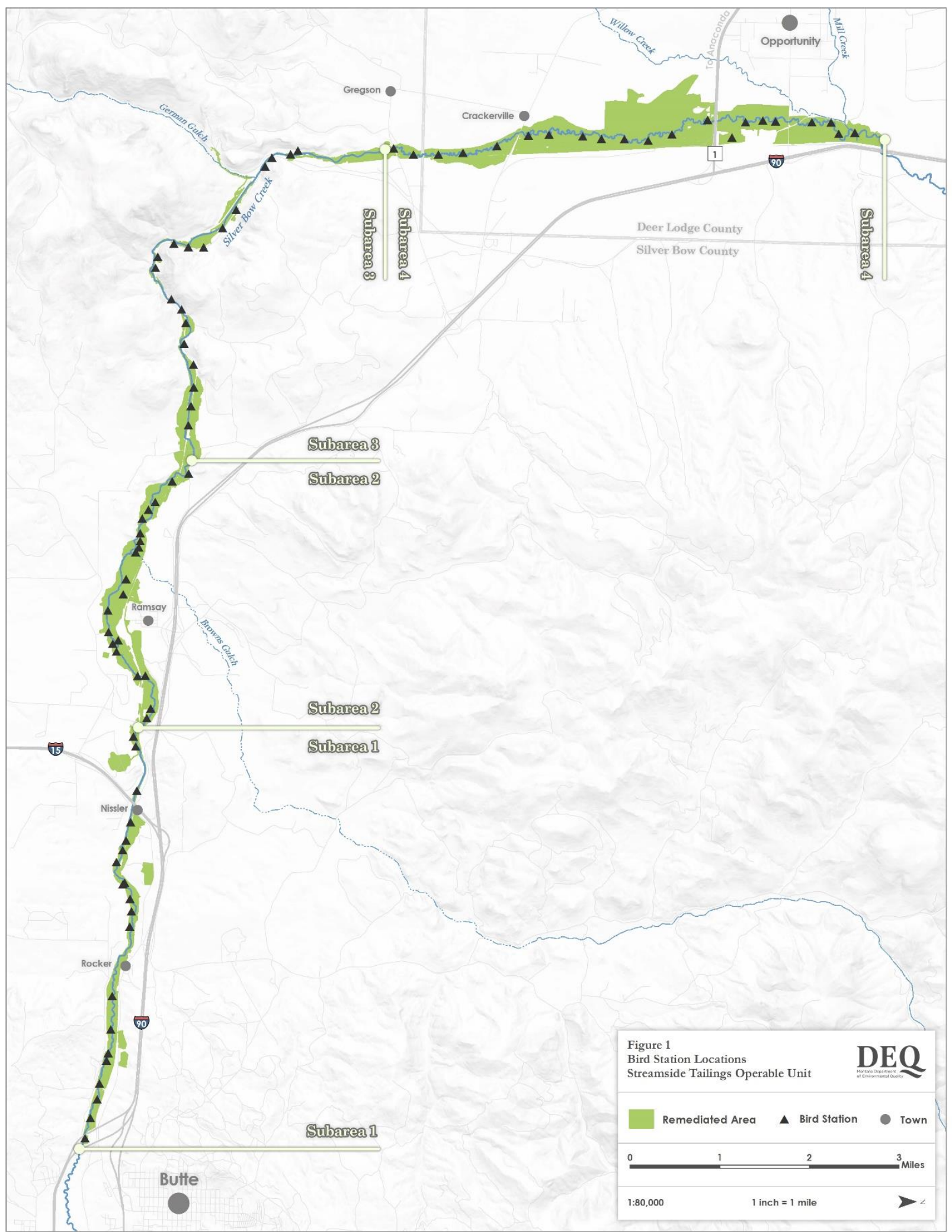

Figure 1. Riparian strip of SSTOU Superfund Remediation and Bird Stations. 
The general layout of the remediated floodplain is relevant to understanding bird sampling and data analysis (Fig. 1). About 20 miles of stream (about 26 miles of bank length with sinuosity) were remediated, providing $11 \%$ more sinuosity than preremediation. This was divided into four subareas of about five linear miles each. Each subarea consists of five reaches, which usually were remediated proceeding downstream one per year. Thus, by the time a subarea was completed, the uppermost reach in that subarea typically had been revegetated for four years, making it harder to detect early temporal trends for subareas. To capture the earliest colonization by birds, we sampled a few reaches as soon as they were seeded. (These are age zero in Figs. 24 and 25.)

We investigated temporal changes in bird use of remediated/restored areas as vegetation developed. The importance of vegetational structure to passerine birds and raptors has been known since the early 1960s (MacArthur, 1964) if not earlier and is a cornerstone of bird ecology. MacArthur divided foliage into three height classes generally corresponding to grasses, shrubs, and trees. He measured the foliage density in each stratum and quantified it with a proportional abundance index (the Shannon function also used in this investigation). He found a linear relation between foliage height diversity and number of bird species. The birds of Australia fitted the same line (Recher, 1969).

Other factors influencing bird use along Silver Bow Creek include migrations, larger landscape habitat patterns, food availability, thermal and security cover, bridges (for cliff swallows), human and dog use (walking-biking trails), vehicular proximity, the stream itself, and other wetlands. The chief structural development has been the growth of tall shrubs (e.g., willows) along the banks of Silver Bow Creek (Fig. 2) and secondarily in other moist sites. Vegetational development is appreciable in wetlands and minimal in uplands apart from noxious weed volunteers.

We did not sample bird use in advance of remediation. Comparing bird use in preremediation and postremediation conditions would only prove the obvious, i.e., waterfowl used the contaminated stream (ponds then hardly existed) while passerines perched in old willows, live and dead. Food and cover were extremely limited, and insect life and stream crustaceans were impoverished. In addition to removing contaminants and providing clean fill to support revegetation, remediation relocated and reconfigured the stream channel. Thus, it would have been impossible to pair locations before and after remediation, making comparison partially subjective. 


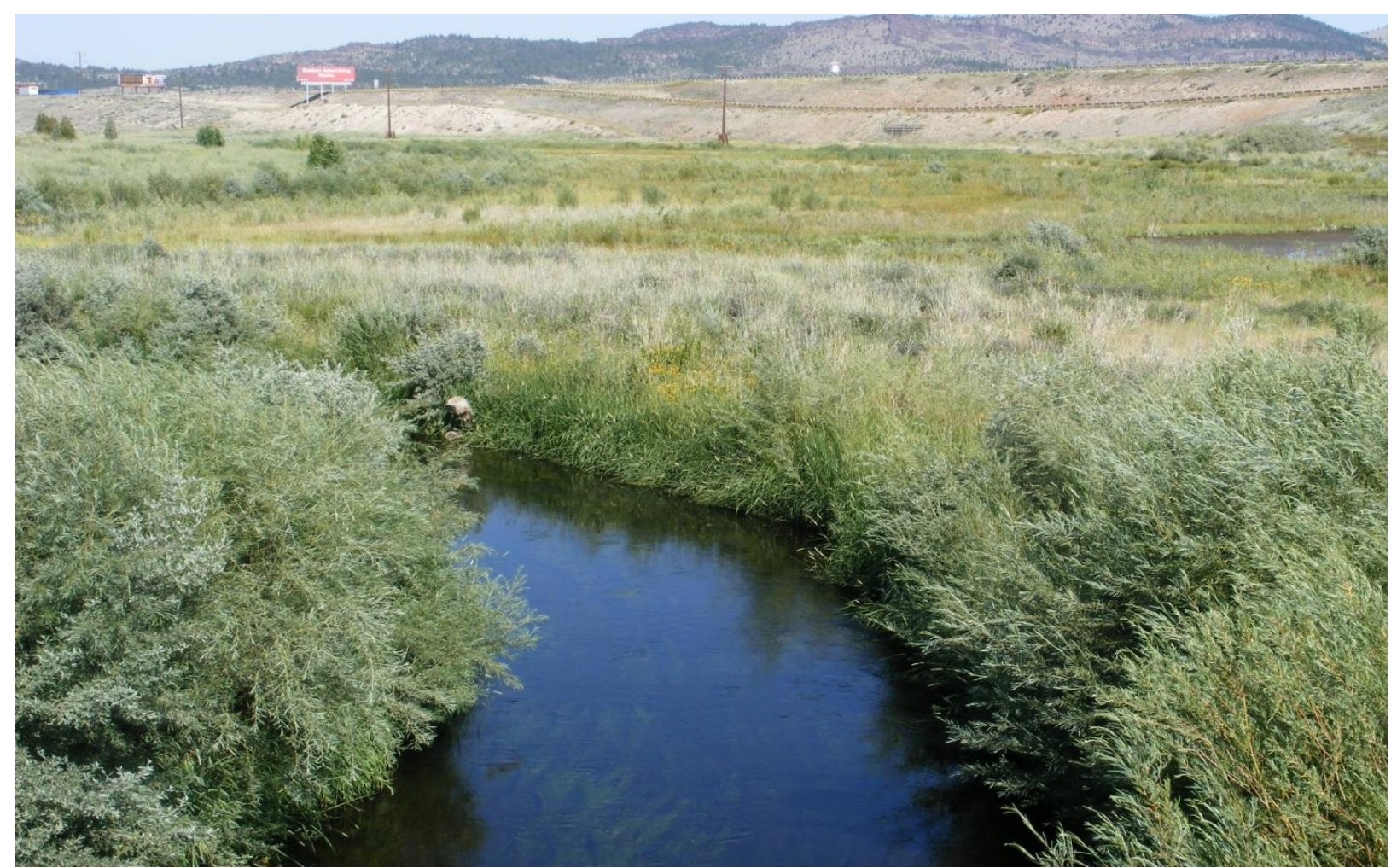

Figure 2. Looking down Silver Bow Creek (foreground) with pond edge on right. Reach F was seeded and the willows transplanted as $10 \mathrm{Ts}$ (7-cu.-in. root volume) in fall 2004-spring 2005. A willow flycatcher was first recorded in Reach F in June 2012, one year before this photo was taken.

\section{BIRDS OF SILVER BOW CREEK}

A total of 19,152 birds comprising 144 species were tallied during sampling. Twenty-eight percent of species are year-long residents; 56\% are summer residents; $3 \%$ are winter residents; and $13 \%$ are migrants. About 38\% of detected species breed locally. The four most abundant species (American cliff swallow [Petrochelidon pyrrhonota], mallard [Anas platyrhynchos], ring-billed gull [Larus delewarensis], and Canada goose [Branta canadensis]) collectively accounted for 39\% of birds tallied. A single individual of 16 species was counted, while nine others species were observed in the remediated area but not counted while sampling.

Trophic composition is shown in Table 1. Omnivores are those birds taking at least 5\% of their energy from a trophic level different than the one they most often feed from.

\section{Sampling}

\section{METHODS}

Each reach was assigned four sample locations, 20 per subarea, 80 in total or about four per linear mile. Sample locations were picked to be roughly equidistant but also to promote a view of 
Table 1. Birds of the SSTOU according to trophic groupings.

\begin{tabular}{lcc}
\hline TROPHIC GROUPING & \% SPECIES & \% BIRDS COUNTED \\
\hline $\begin{array}{l}\text { Herbivores (waterfowl, doves, finches) } \\
\begin{array}{l}\text { Omnivores (waterfowl, gulls, jays, thrushes, } \\
\text { starlings, waxwings, sparrows, blackbirds) }\end{array}\end{array}$ & 38 & 10 \\
$\begin{array}{l}\text { Invertebrates (waterfowl, shorebirds, } \\
\text { flycatchers, swallows, dippers, wood warblers) }\end{array}$ & 35 & 54 \\
$\begin{array}{l}\text { Vertebrates (waterfowl, cormorants, herons, } \\
\text { birds of prey, cranes) }\end{array}$ & 17 & 34 \\
\hline
\end{tabular}

special habitats, such as the stream and ponds, along with ease of access, including when snow or mud limited driving. Usually one subarea was sampled each year (two one year), but additionally some reaches were sampled annually as soon as seeded or vegetated to provide bird data from the initiation of revegetation.

Sampling was timed for late March, April, May, and June, the same approximate date each year, and took less than four hours per subarea (20 stations) to complete. Once in place, each stop was sampled for five minutes using a stopwatch, but birds flushed approaching sample points also were counted. The sample form (Fig. 3) was shortened from a form used for the USDA Forest Service, Region 1. The Forest Service form had many more fields for environmental factors to such an extent that it took longer to fill the environment section than to complete the bird census. Even the truncated form we used provides more data than we have summarized. (One can hardly imagine summarizing cloud cover or the Beaufort wind scale descriptors for years of bird data.)

Birds were identified by sound or call as well as by sight. Although birds could be seen and heard beyond the confines of remediation, only birds in the immediate vicinity of remediated habitat were recorded. High-flying migratory birds were not counted.

Thompson's 1980 breeding-bird-survey work in eastern Montana, a useful reference, found that changing observers manifested a sharp drop in similarities. "This demonstrates the extreme importance of maintaining observer continuity for long-term monitoring," even with equally skilled observers. One of the authors conducted the field work from start to finish. Whereas 


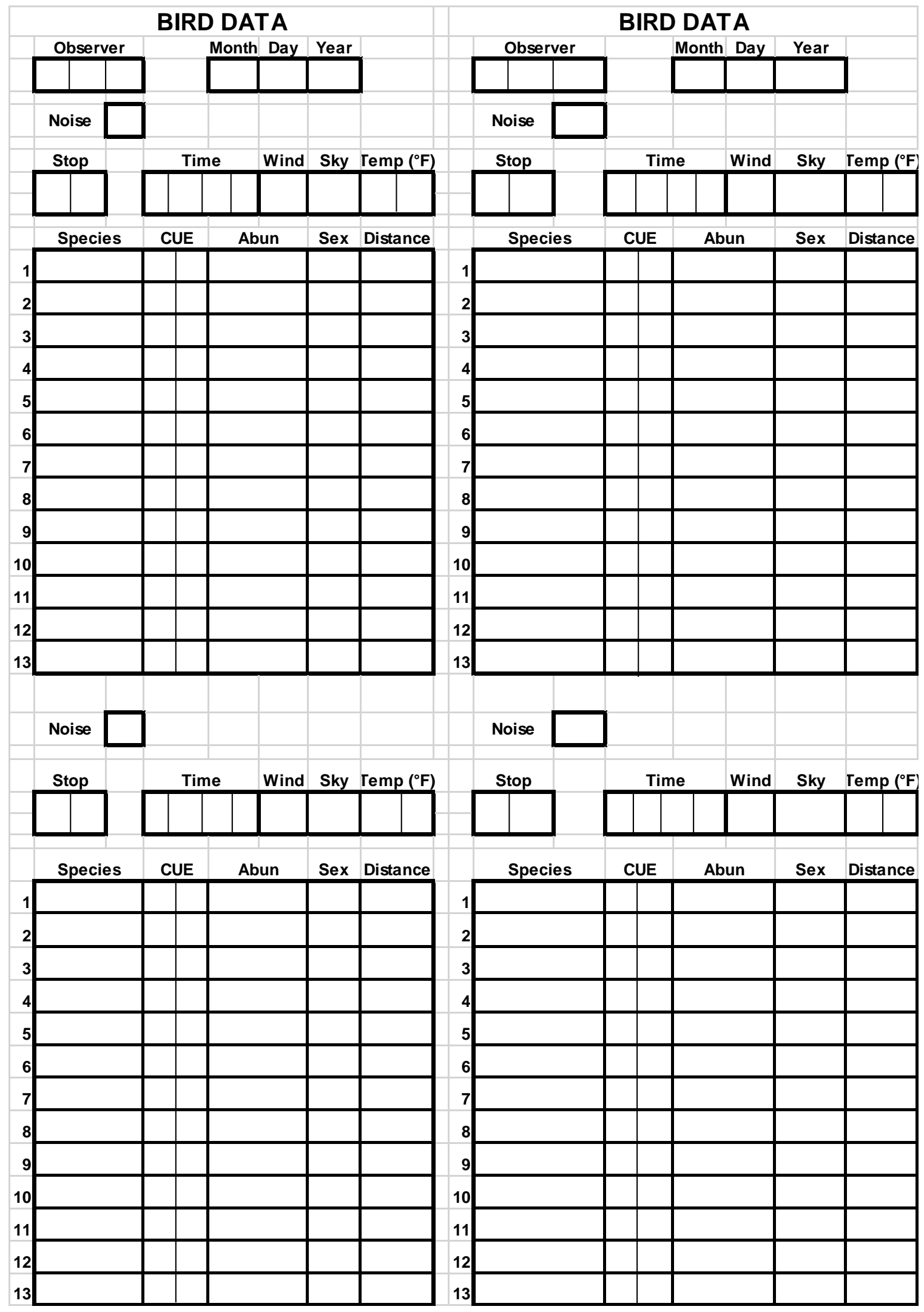

Figure 3. Bird census sample form. 
Thompson characterized pre-impact bird communities in great detail and hypothesized impacts and recovery, our work focuses on the recovery process. For most parameters, it was astonishingly rapid; for others it was delayed.

\section{Data Analysis}

Most data are summarized as sums and arithmetic means. Variability in species composition was evaluated through Sorenson's index. It sums the quantity of each species in common relative to the summed quantity in each individual set being compared. It is intuitive in that a community compared to itself is $100 \%$ similar.

$$
\text { Sorenson (1948) Similarity Index }=\frac{2 C}{-------}
$$

Where $\mathrm{C}$ is the quantity of birds in common summed for all species; $\mathrm{A}$ is the number of birds sampled in year (or area, etc.) A; B is the same for year or area B.

To combine richness with relative abundance, we used Claude Shannon's formula (Shannon and Weaver, 1949) and could be called evenness. (Relative abundance means the counts are converted first to percentages, which facilitates comparisons between years or areas.) Whittaker (1972) thought the Shannon Index $\left(\mathrm{H}^{\prime}\right)$ to be the best all-purpose expression of "equitability" in use. The all-purpose Shannon Index here was applied to bird and species counts and bird counts/ station, each relativized. The Shannon formula follows:

$$
\mathrm{H}^{\prime}(\text { Shannon Index })=-\sum p_{i} \ln p_{i}
$$

Where: $p_{i}$ is the relative abundance of entity (here species) $\mathrm{P}$ expressed as a decimal.

\section{INHERENT VARIABILITY}

Greater similarity among proximate years and lower similarity among temporally distant years would provide the basis for distinguishing trends through time. The following matrix (Table 2) for our most sampled subarea, SA 1, was computed using pooled data for all four months, which should have the effect of promoting similarity (from the central limits theorem) as compared to monthly data. One would expect the highest similarities along the diagonals immediately below 
Table 2. Similarity matrix for Subarea 1 shows percent compositional similarity among years.

\begin{tabular}{rrrrrl}
\hline 2005 & 100 & & & & \\
2006 & 66 & 100 & & & \\
2010 & 86 & 61 & 100 & & \\
2013 & 60 & 56 & 64 & 100 & \\
2017 & 60 & 50 & 82 & 71 & 100 \\
& 2005 & 2006 & 2010 & 2013 & 2017 \\
\hline
\end{tabular}

the 100s and the lowest similarities in the lower left corner, but only the latter expectation is met in a general way.

Most similarities are rather low, and even in the two most proximate years (2005 vs. 2006), bird species composition was only $66 \%$ similar, which is also the mean of all similarities. The two highest similarities (2010 vs. 2005 and 2010 vs. 2017) are not particularly close in time nor are they readily explainable. Low similarities usually originate with the most common species.

Species composition data for Subarea 2 indicates consonant similarities (Table 3). In comparison to SA 1, SA 2 is more expansive, has considerably more wetlands, less human visitation, less vehicular traffic, and less altered adjacent land uses, none of which seem to matter much to temporal similarities.

One thing we have learned is that while the species composition varies, the state remains fairly consistent. Mean similarity in both SA 1 and SA 2 is 66\%. The few high similarities $(>80 \%)$ in both areas have no apparent explanation.

Table 3. Similarity matrix for Subarea 2 shows similar compositional similarity there.

\begin{tabular}{rrrrl}
2009 & 100 & & & \\
2012 & 60 & 100 & & \\
2014 & 81 & 72 & 100 & \\
2016 & 56 & 64 & 63 & 100 \\
& 2009 & 2012 & 2014 & 2016 \\
\hline
\end{tabular}


A single species can, at times, greatly influence overall bird abundance. This is best demonstrated by example. In an extreme and uncommon case, cliff swallows at one or two stops can outnumber all other birds observed at the other 18 stations. They distort species and station equitability as well as monthly counts and other metrics.

Cliff swallows usually arrive in May and situate at bridges, which provide nesting structure. The SSTOU has six such structures. The other key habitat factor is flying insects, which restored Silver Bow Creek provides pretty much everywhere. Should they arrive in April, as occasionally happens, that confounds the temporal abundance interpretation for that month. They are early risers in warm weather and late risers in cold, so whether they are seen on any given date depends on temperature too. Fig. 4 shows the variability in May-June cliff swallow abundance at Stations 1 and 2 located near two Interstate Highway bridges just west of Butte. Other species can spike bird abundance. In June, 2005, 80 gulls turned up at Station 9. In April 2009, 120 Bohemian waxwings were tallied at Station 34 - the only time this species was observed in the project area.

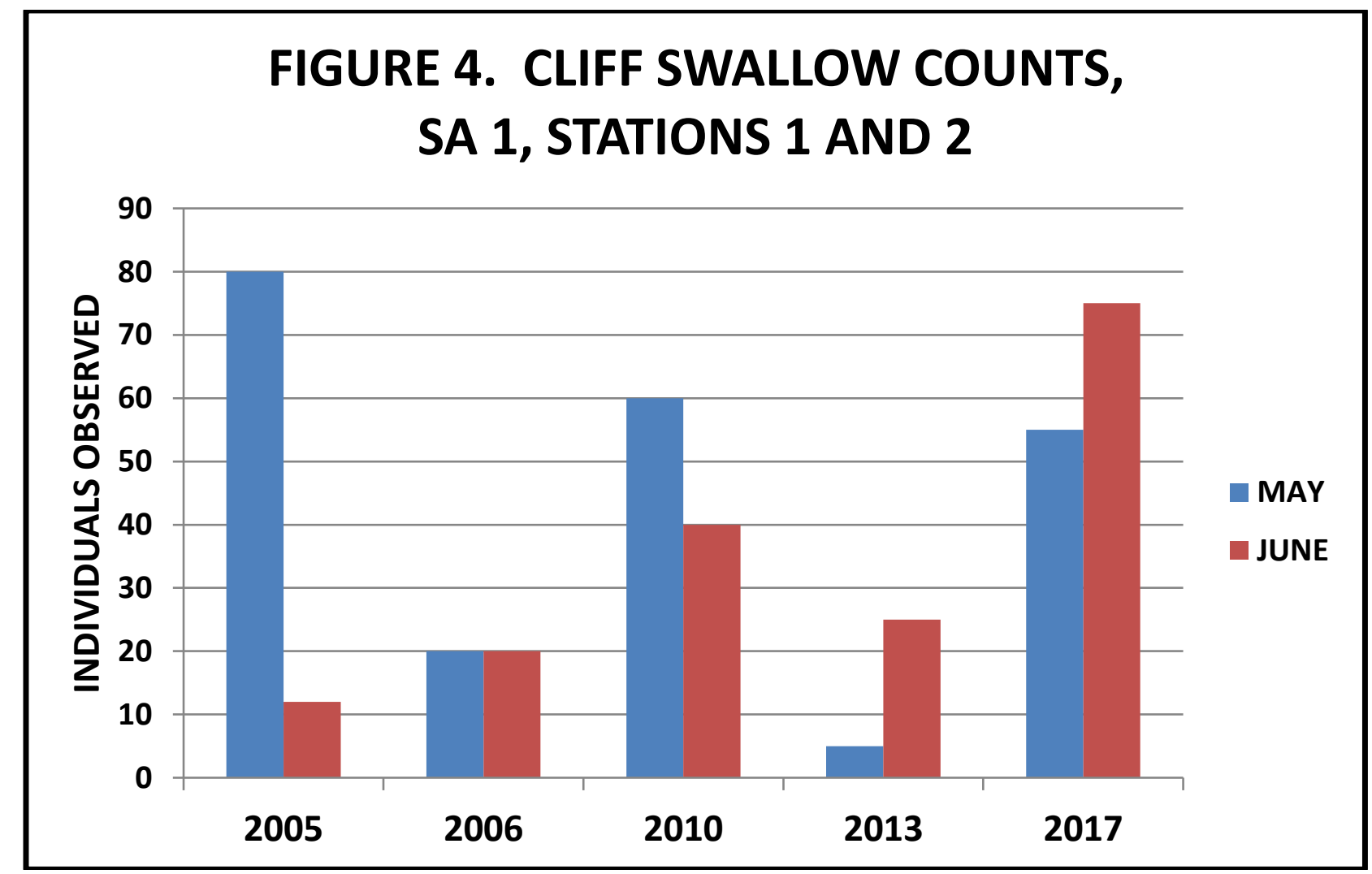

Figure 4. May-June cliff swallow abundance at a pair of adjacent stations in upper Subarea 1. 


\section{Effect of Sampling Date}

Is the sampling protocol in conjunction with inherent variability in not only bird abundance but also species composition up to the task of detecting temporal trends? The actual amount of time spent sampling, five minutes per station timed with a stopwatch, summed over 18 years, was only 118 hours and 40 minutes at the end of 2017. How much does simply sampling on a different date influence estimates of bird abundance and diversity?

Double sampling took the form of sampling twice each month one week apart in 2014 in SA 2. Additional sampling inevitably results in more species being observed as more transitory bird use is recorded. Of the 16 fresh species observed in 2014 in SA 2, 10 were seen on the first date, six on the second date. Since the interval between the paired dates is one week and the next sampling is three weeks away, this is about what one would expect. Some of the second-date additions might have been picked up the following month on the normal sampling date.

Table 4 summarizes the net effect of double-sampling. The coefficients of variation are large because each mean represents four values, one from each of the four months, and it is a given that bird use increases dramatically from March to May.

For three parameters in Table 4, the net difference among sample dates was nil. For species equitability, the difference was about 7\%. For species/station, and this also relates to equitability, the difference was about $11 \%$. This is because spring arrivals really do increase the species count from March to May.

While Table 4 shows net effects, the monthly dynamic is obscured. Fig. 5 provides an example of the monthly dynamic for species richness. Richness was greater on the second date in March and April, lower on the second date in May and June. To a large extent, they canceled, and the net effect was less than one species per month. A trend not documented by Table 4 is that the effect of date on species is more pronounced in late winter due to migratory arrivals in March and April than later in spring, so it is not sample error. In late winter, later sampling date tends to capture more species more equitably distributed, a trend also seen in other years and subareas. Summing up monthly trends, the effect of date on species is more pronounced in late winter (March and April) than in spring due to migratory arrivals. 
Table 4. Summary of differences between first- and second-date sampling for all four months pooled. (Means with two-tailed $90 \%$ confidence intervals. $\mathrm{N}$ in each case is 4 , the four months.)

\begin{tabular}{lclccc}
\hline PARAMETER & $1^{\text {st }}$ DATE & $\begin{array}{l}\text { COEF. } \\
\text { VAR. }\end{array}$ & 2 ${ }^{\text {nd }}$ DATE & $\begin{array}{l}\text { COEF } \\
\text { VAR. }\end{array}$ & DIFFERENCE \\
\hline Birds/Station & $15.0+-4.0$ & $20 \%$ & $15.0+-1.3$ & $6 \%$ & 0 \\
Equitability/Station. & $2.4+-0.5$ & $16 \%$ & $2.5+-0.2$ & $6 \%$ & +0.1 \\
Species/Station & $5.8+-3.2$ & $41 \%$ & $6.5+-2.3$ & $27 \%$ & +0.7 \\
Equitability/Species & $2.7+-0.7$ & $20 \%$ & $2.9+-0.6$ & $14 \%$ & +0.2 \\
Species Richness & $36.2+-17.0$ & $34 \%$ & $35.5+-11.6$ & $24 \%$ & -0.7 \\
\hline
\end{tabular}

Figure 5. Species Richness From Double Sampling

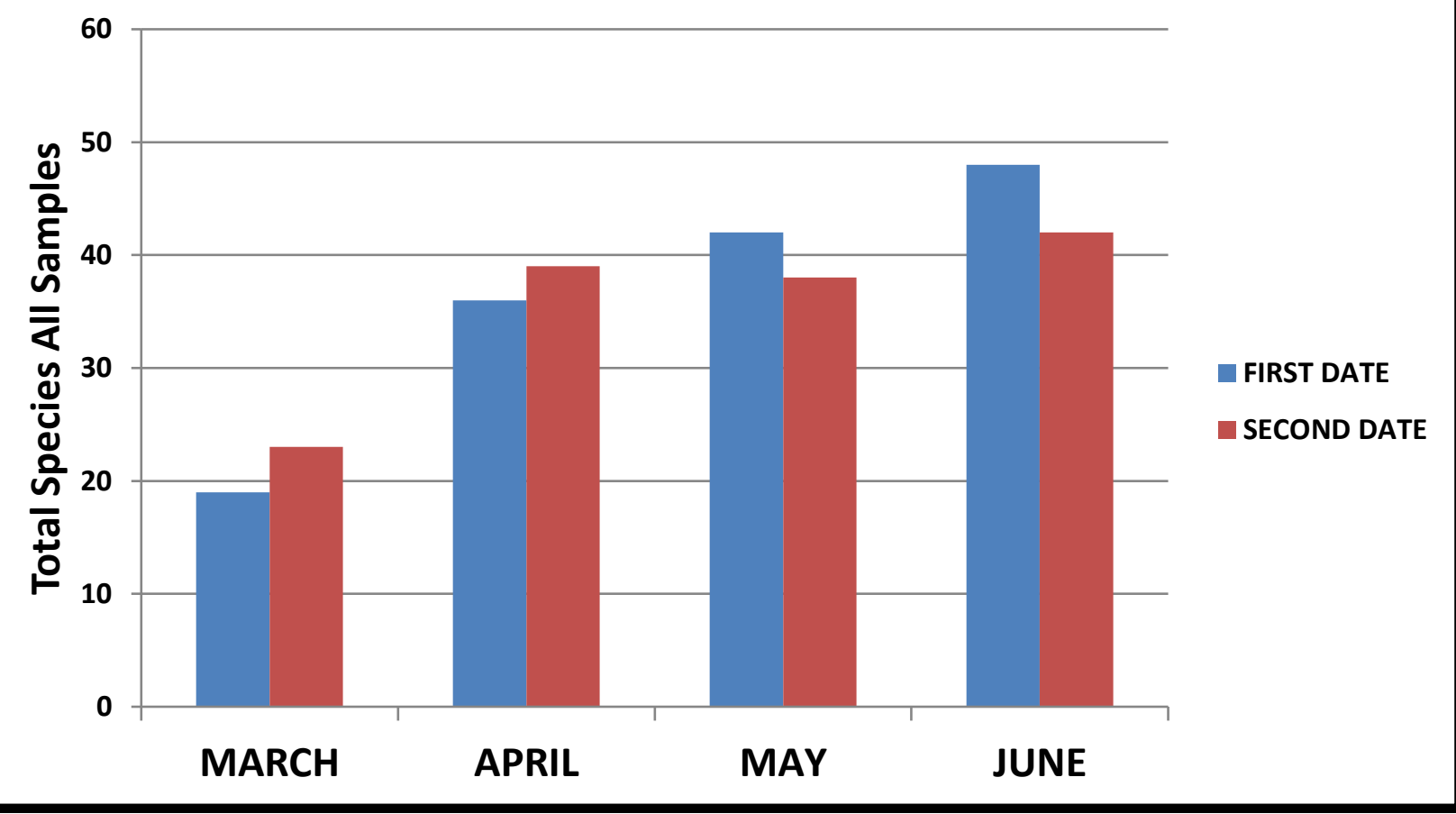




\section{TRENDS IN BIRD QUANTITY}

The rapidity with which bird use establishes following revegetation has been consistent throughout all four subareas and is one major finding. Water, especially ponds, provides instant habitat as soon as construction completes and accounts for much immediate use. How little bird abundance continues to increase with time, keying mainly for vegetational development, is perhaps surprising. Subarea 1, which we sampled periodically over 13 years, shows no clear temporal trend in bird use (Fig. 6). (Mean birds per station, rather than total bird counts, was used to allow comparison with data presented later from fewer than 20 reaches.) This subarea wasn't sampled until revegetation was a few years old in most reaches.

Turning to Subarea 2 (Fig. 7), the 2007 and 2008 data represent just the first three reaches when the lower two reaches were yet unremediated. The first three reaches include most of the pond complex that distinguishes SA 2 from SA 1 and is largely responsible for higher bird and species counts there. Late winter bird use increased after the first sampling, but there was no subsequent change, nor is a temporal trend discernible in May and June for the 10-year period. (April 2009 was a banner time for American coots (Fulica americana), American widgeons (Anas americana), and avocets (Recurvirostra Americana), none of which are usually numerous in the SSTOU.)

Water is quickly visited by waterfowl. In late winter, the proportion of waterfowl in the three reaches with most open water peaked in the first year (Fig. 8) and declined quickly.

\section{TRENDS IN SPECIES RICHNESS AND EQUITABILITY}

Biodiversity is almost always computed for species not because the species is the best unit for diversity, but because it is the fundamental unit of taxonomy. Most biological inventories use species because they are countable, as are the number of individuals of each species. Traditional measures of species diversity treat all species as being equal in all respects save abundance. The Shannon index gives relative abundance somewhat more weight than richness.

Fig. 9 for SA 1 shows a clear trend of increasing richness with time in April and May, whereas March and June indicate an increase from the first sampled year but no subsequent directional change. Another way to look at richness is species density, the mean number of 

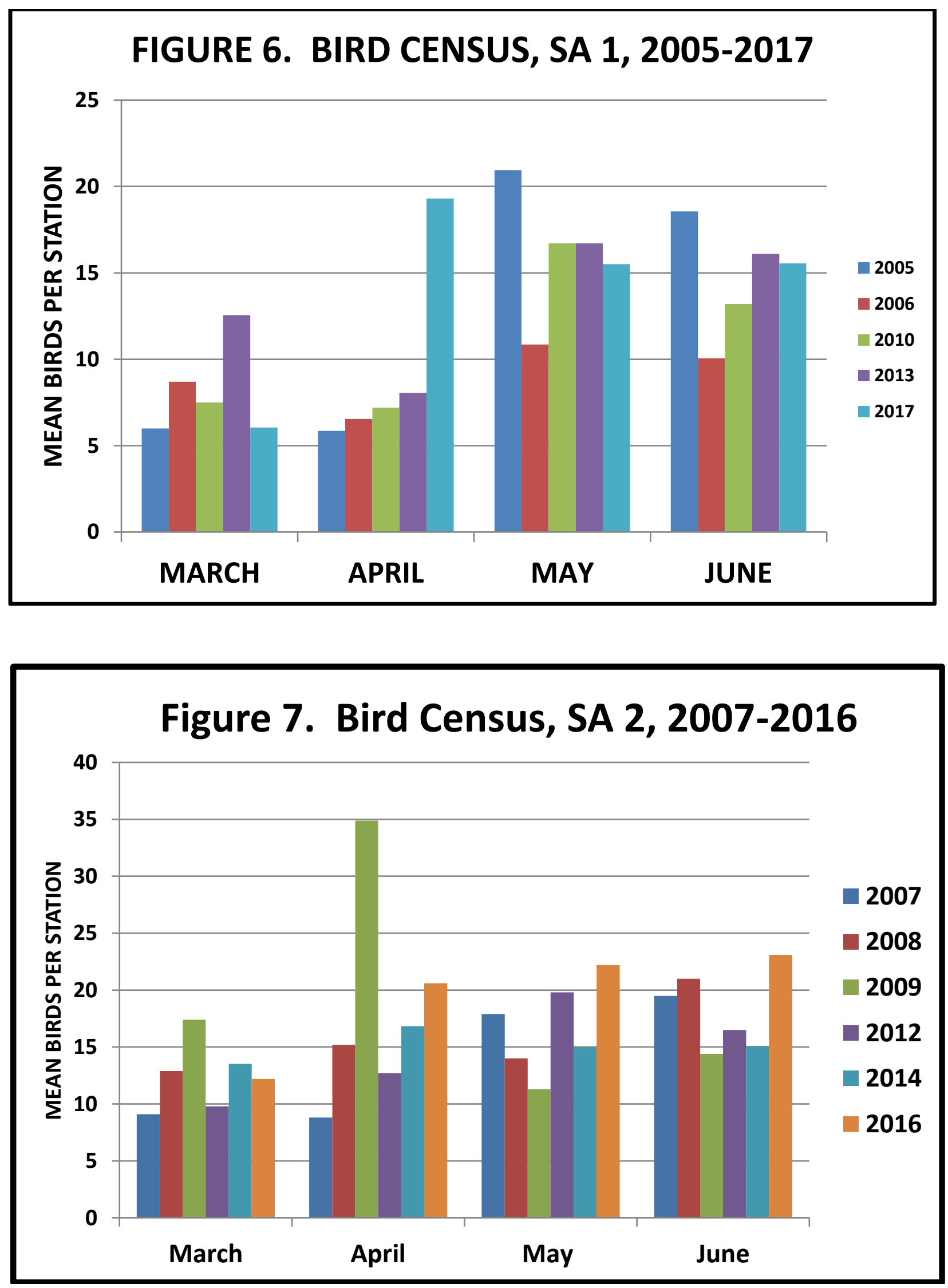

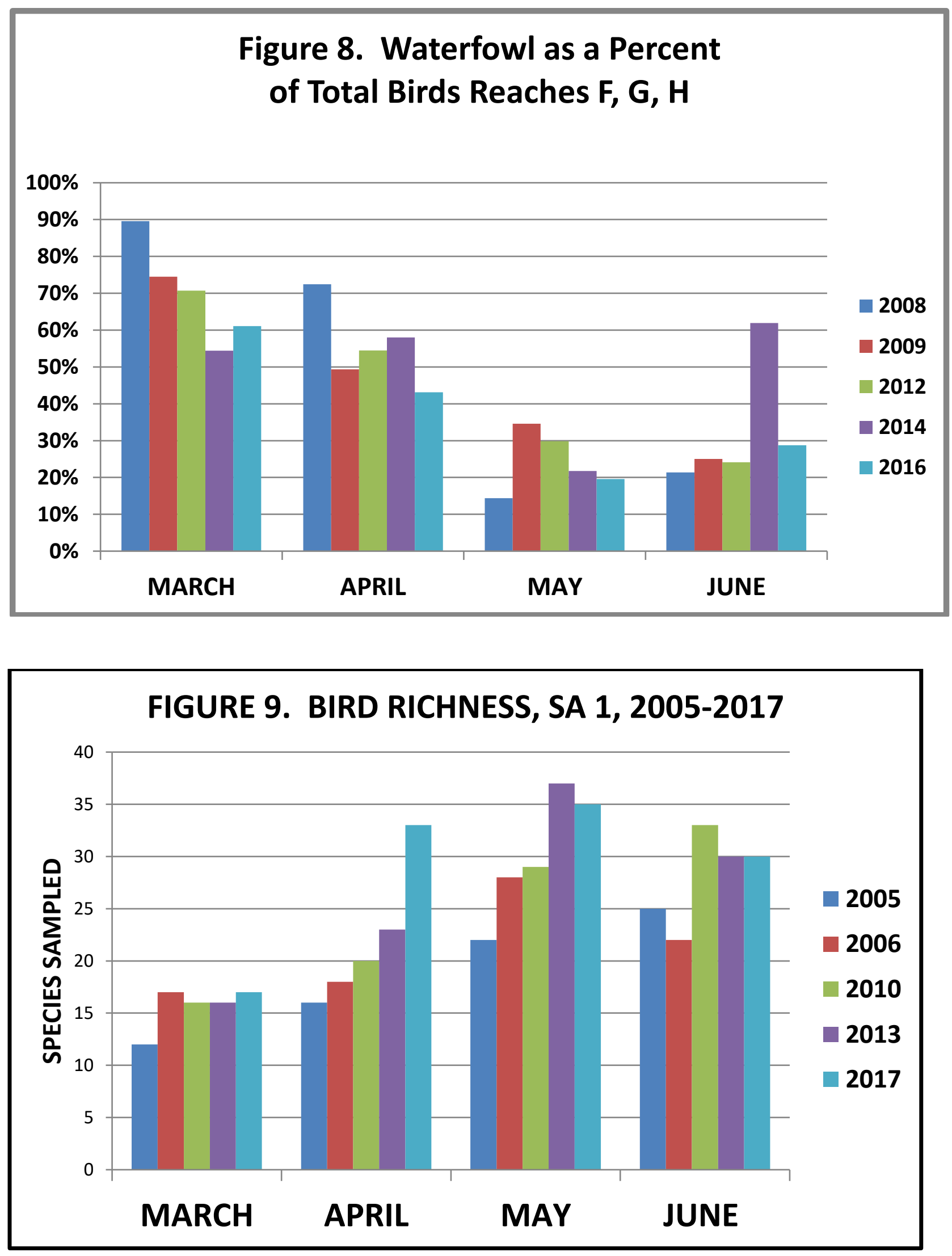
species per station (Fig. 10). This has the advantage of application to data sets with an unequal number of stations. In SA 1, species density increased over time, but especially in May and June. The spike in April 2017 is an anomaly - April 2017 weather was more like a normal May.

Considering species counts for all stations in SAs 1 and 2 and all sample years, about twice as many species increased in abundance over the monitoring period as decreased (Table 5).

Table 5. Temporal trends in bird abundance for species.

\begin{tabular}{|c|c|c|c|}
\hline & INCREASE & NO TREND & DECREASE \\
\hline & \multicolumn{3}{|c|}{ 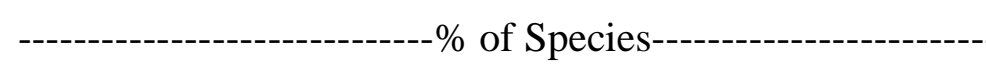 } \\
\hline Subarea 1 & 33 & 53 & 14 \\
\hline Subarea 2 & 39 & 44 & 17 \\
\hline
\end{tabular}

In SA 2, species density shows an upward trend over time (Fig. 11), although it shows a stronger temporal trend in spring than later winter. (Only 12 stations were sampled in 2007 and 2008 to capture the early dynamic.) Pooling the yearly data (losing the monthly dynamic), Fig. 12 shows that about $7 / 8$ s of the variance in species density is attributable to age.

Claude Shannon's combination of relative abundance with richness shows an increase in late winter in SA 1 (Fig. 13) with a clearer increase over the four-month sampling period in SA 2 (Fig. 14). Pooling the annual data as in Fig. 12, and Fig. 15 confirms a strong relation $(\mathrm{r} 2=0.75)$ between field age and species equitability. Thus, from a variety of perspectives (Figures 9-15), species diversity increased over time, unlike bird quantity (Fig. 6 and 7).

\section{TRENDS IN TROPHIC STRUCTURE}

Trophic structure defined as the percentage of birds in each of four trophic classes (from p. 6) was hoped to provide insight into temporal changes, but Figure 16 representing SA 2 shows a temporal increase only for omnivores and corresponding decline in invertebrates. The increase in omnivores is convincing (Fig. 17). But SA 1 (Fig. 18) indicates a greater prevalence of invertebrates (and fewer omnivores) than in SA 2 with more temporal variability and even less trend. Thus, no convincing trophic trends are seen in both Subareas 1 and 2. 


\section{FIGURE 10. SPECIES DENSITY, SA 1, 2005-2017}

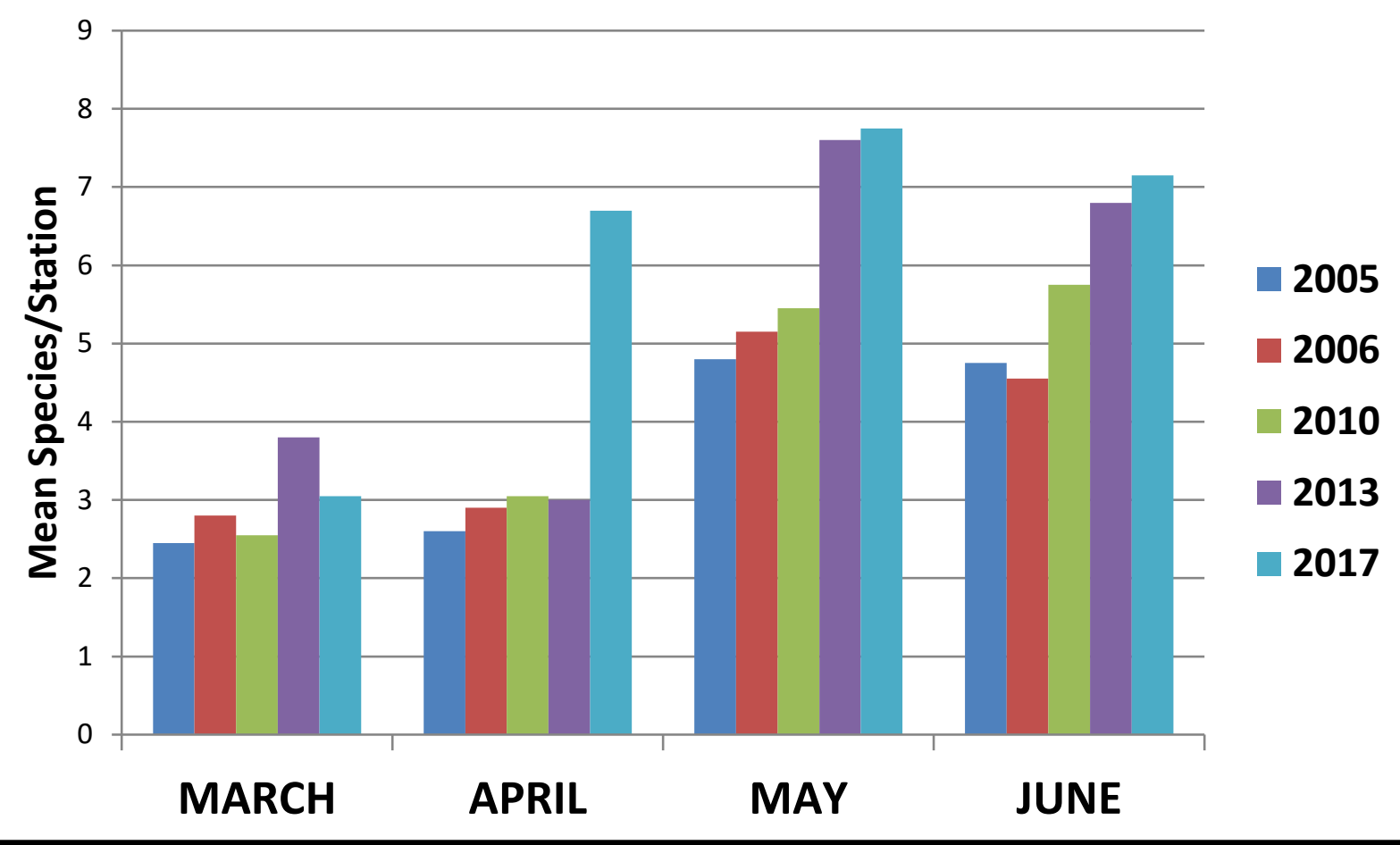

Figure 11. Species Densitiy, SA 2, 20072016

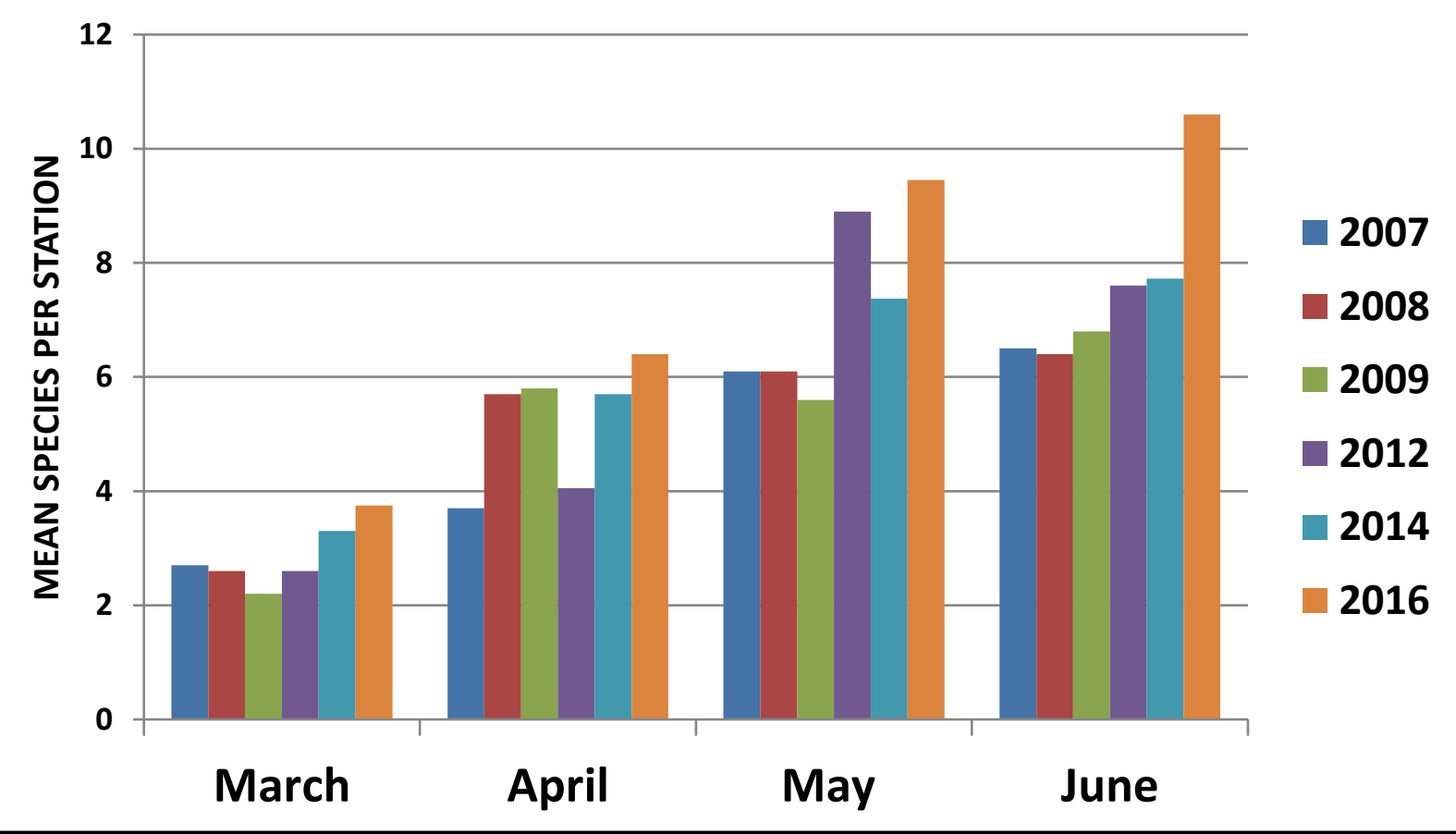



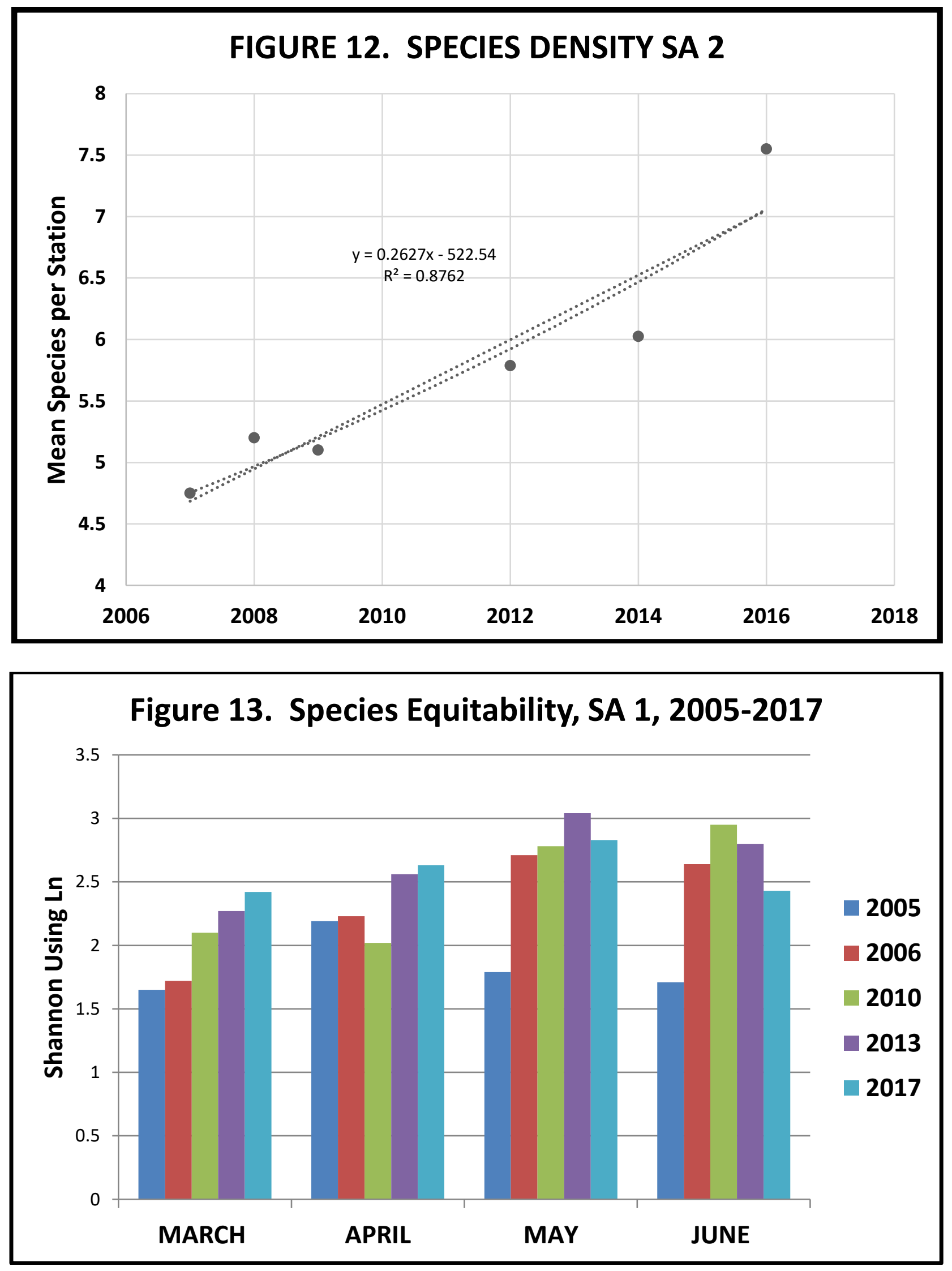
Figure 14. Species Equitability, SA 2, 2007-2016

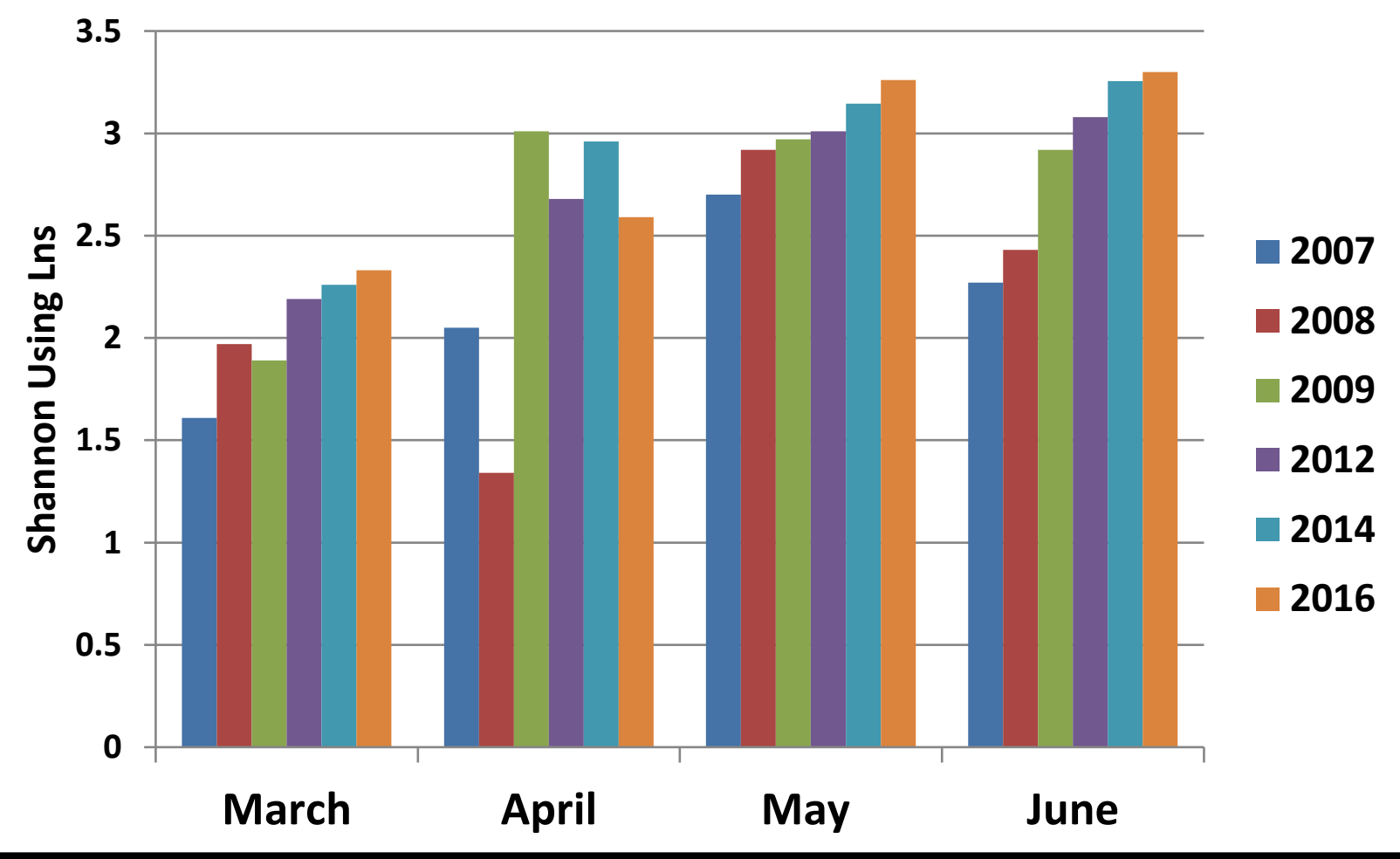

FIGURE 15. SPECIES EQUITABILITY SA 2

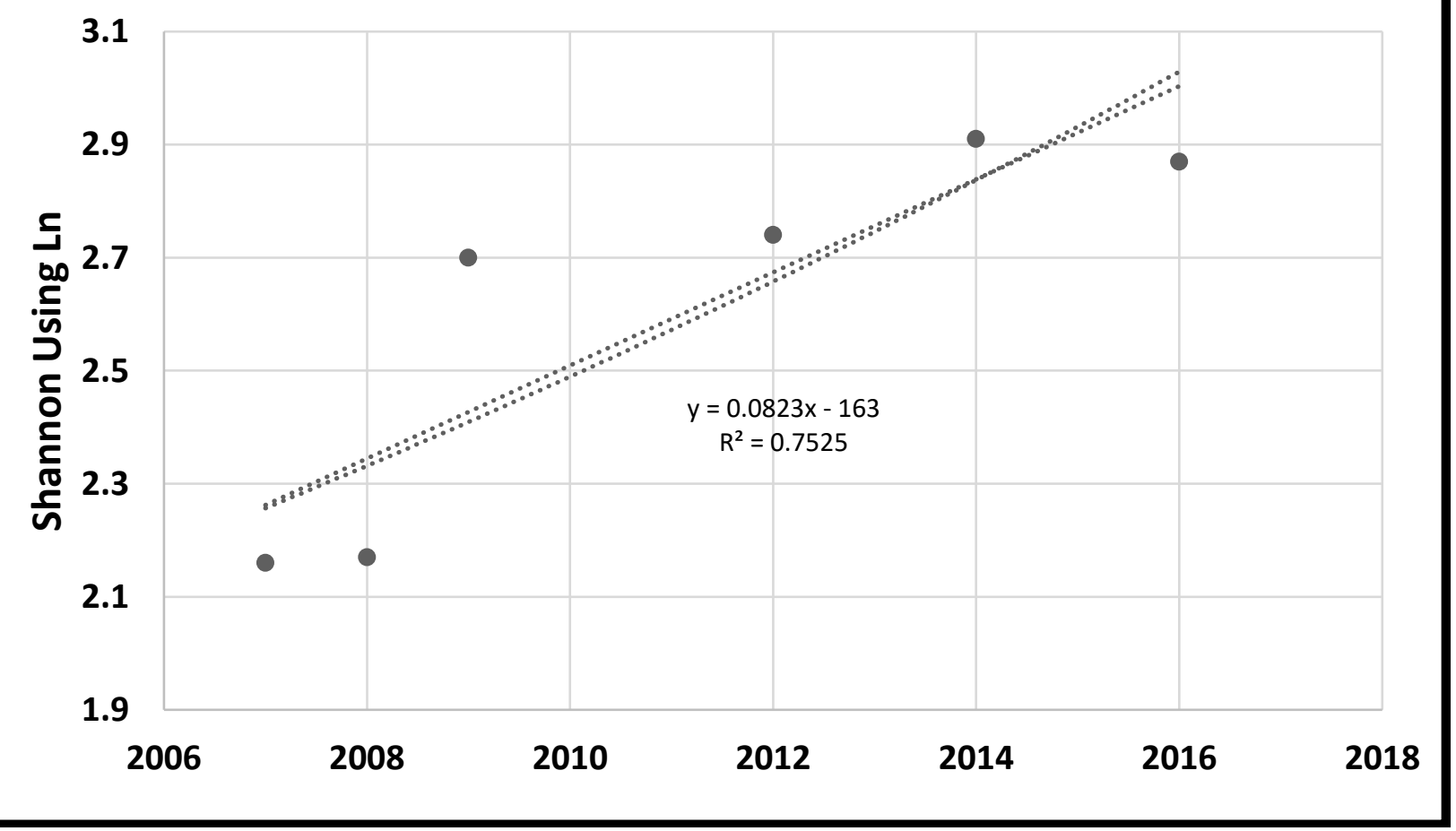


Journal American Society of Mining and Reclamation, 2019 Vol.8, No.2
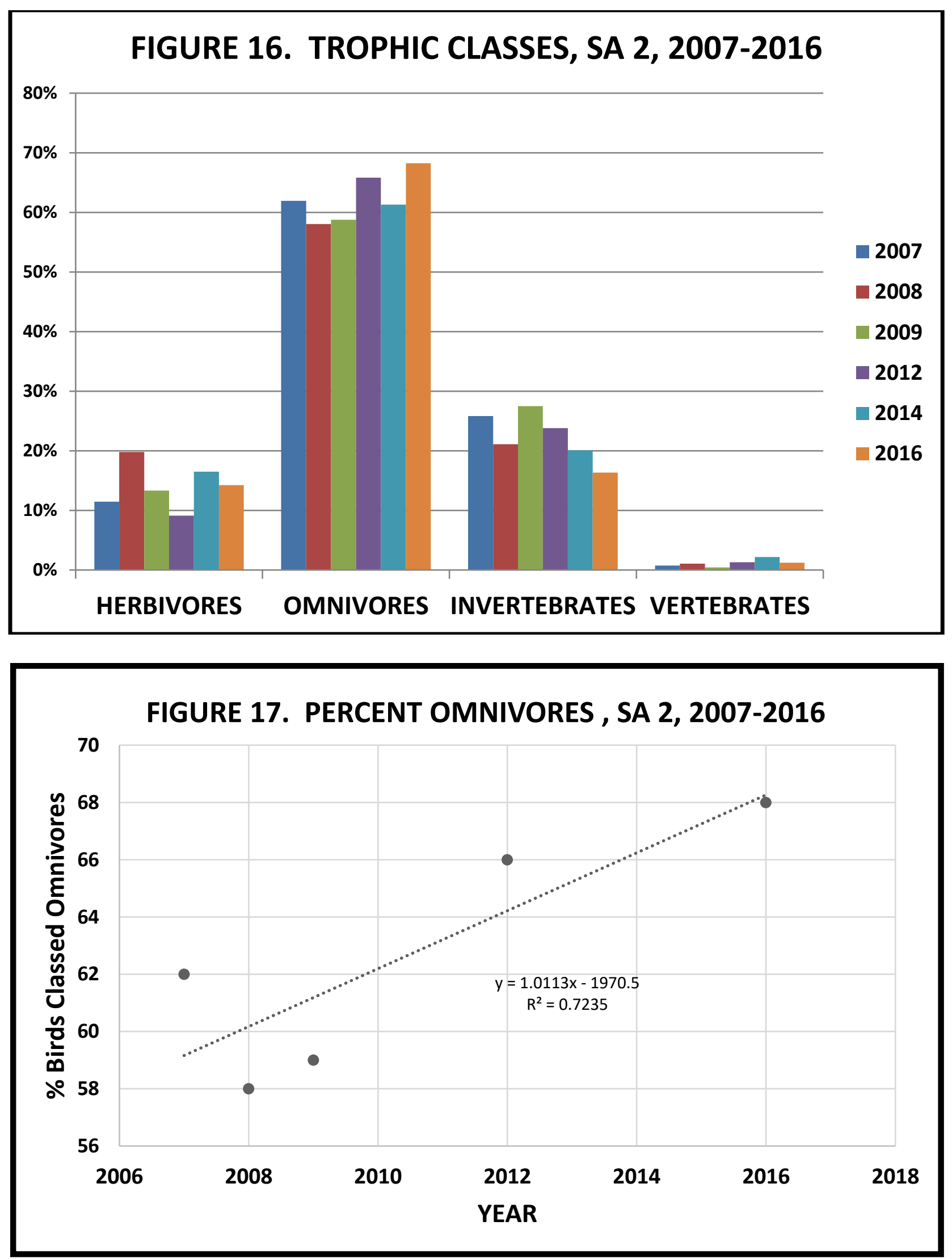


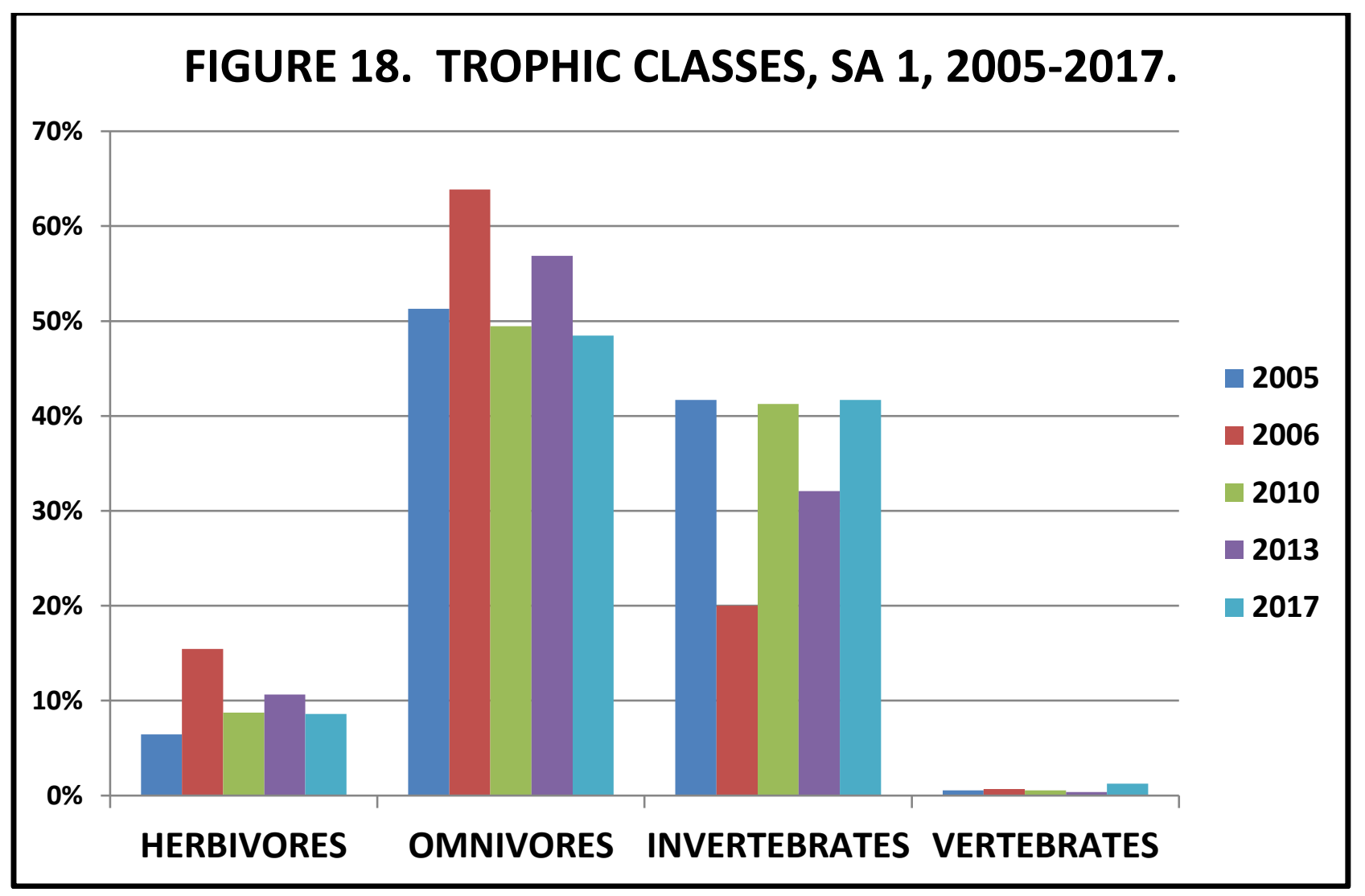

\section{HABITAT HETEROGENEITY AND TRENDS IN HABITAT USE}

Each subarea represents a particular set of habitat factors: vegetation types, open water and other wetlands, human and dog visitation, adjacent or nearby transportation corridors, and nearby landscapes with their own characteristic seasonal bird use. Subarea 2 is not a replicate of Subarea 1 but rather a different set of in situ habitats in an intrinsically different setting, and they were sampled in different years. In essence, they comprise independent samples.

Fig. 19 using data from SA 1 shows how bird use varies among stations and is typical of other subareas. The first station (and to lesser degree the next three stations) is influenced by cliff swallows, whereas Station 17 overlooks an 11-acre wetland complex. The final stations have a slight but perceptible influence from a wetland just south of the remediated area.

Equitability also can be used to express differential bird use among stations. The pattern of relative abundance among stations is surprisingly consistent (Fig. 20) with most variation attributable to migratory birds in late winter. 


\section{FIGURE 19. AVERAGE BIRDS COUNTED PER STATION, SA 1, 2013 AND 2017}

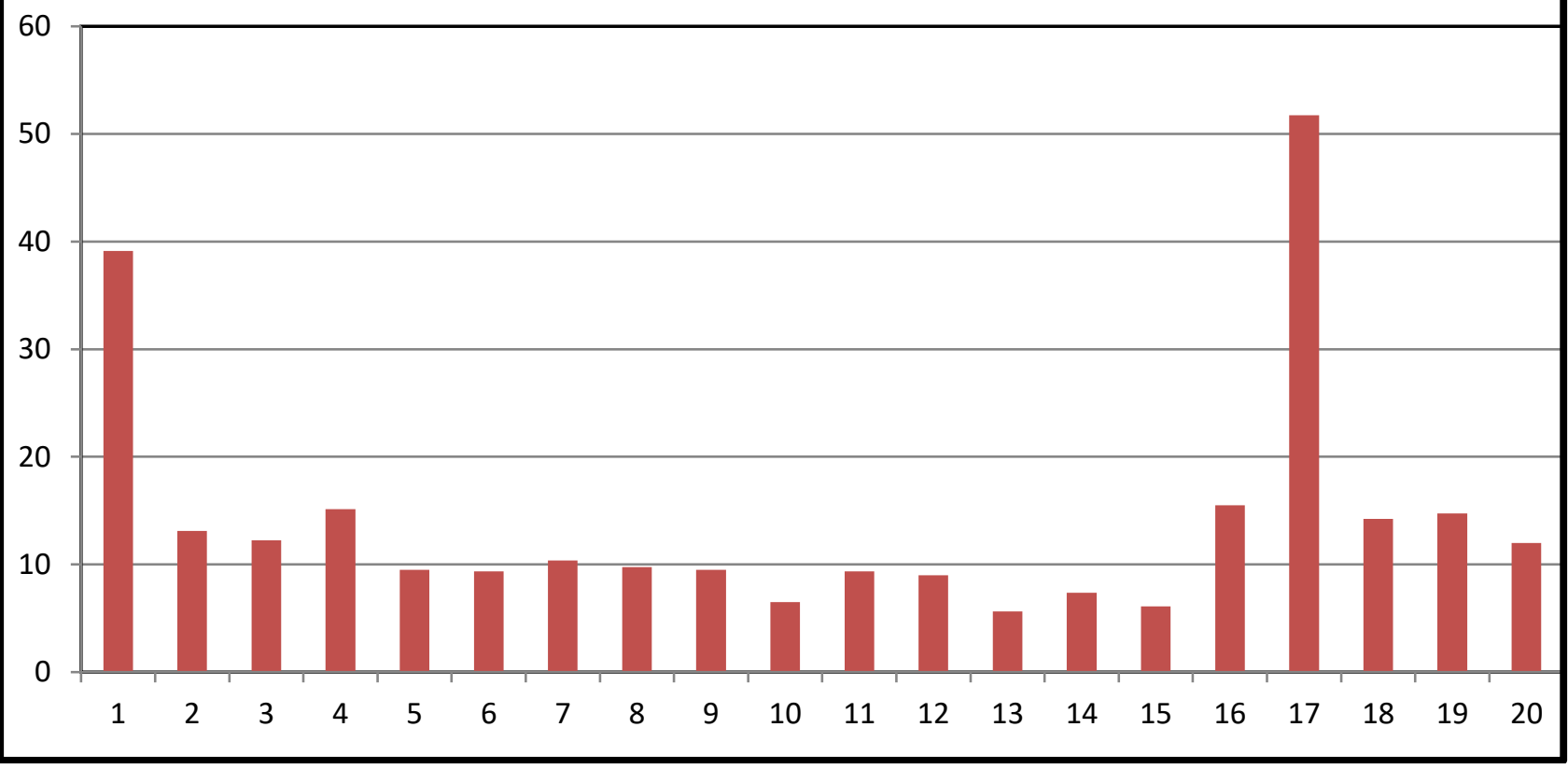

FIGURE 20. BIRD COUNT EQUITABILITY AMONG STATIONS, SA 1, 2005-2017

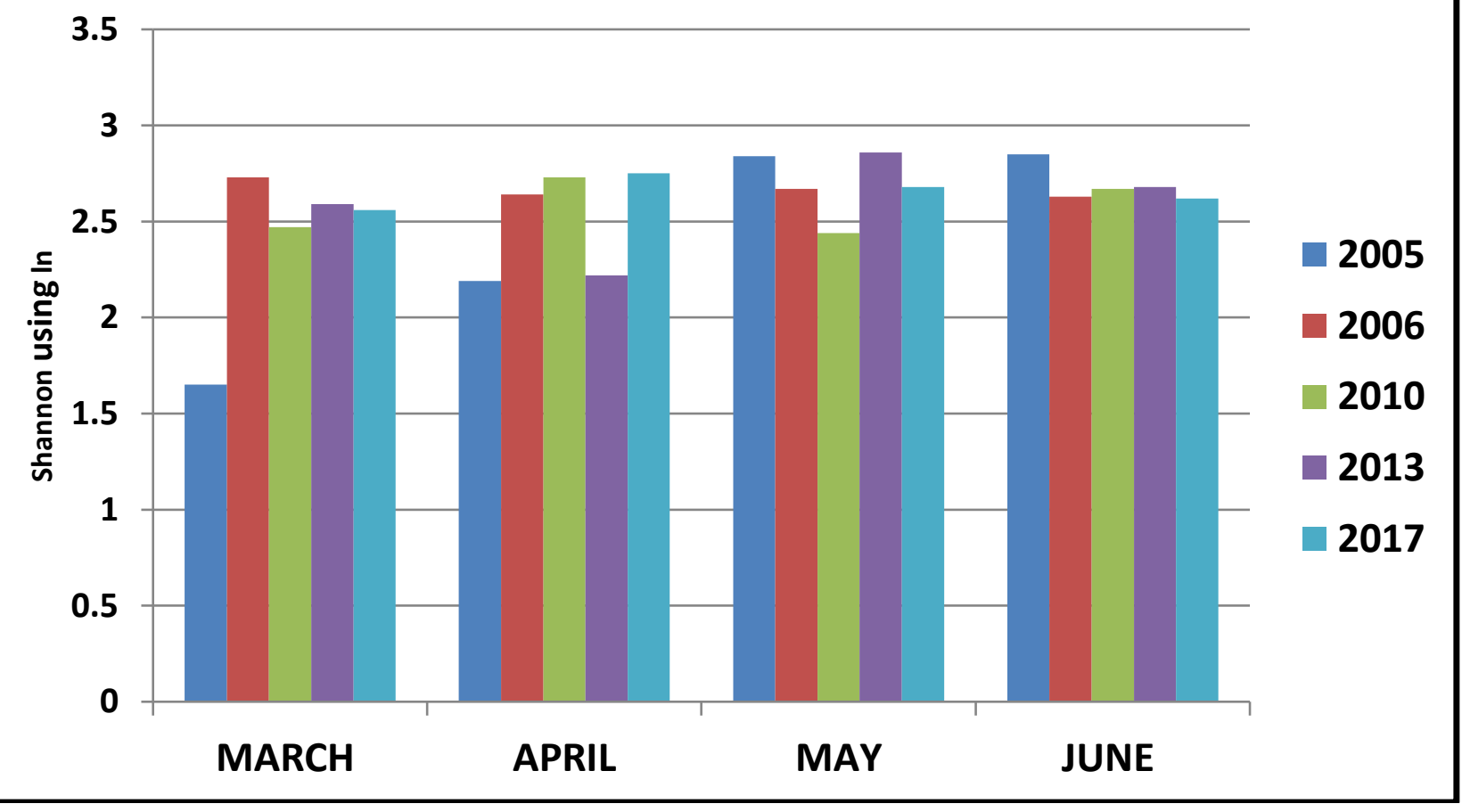


We identified five habitat types and analyzed bird use at the two major ones: tall shrubs along the creek $(n=37$ stations or $46 \%)$ and wetlands $(n=16$ or $21 \%)$. Tall shrub communities develop over time (Fig. 2). These samples first represented herbaceous vegetation (meadows) that transitioned into tall-shrub communities. Unanalyzed were permanent meadows (poorly represented in the older data), stations in the canyon where the remediated zone is narrow and preremediation vegetational structure remains (Fig. 21), and six stations at bridges with elevated cliff swallow counts.

\section{HABITAT SPECIALISTS}

So far, we have treated bird use as the sum of parts, wherein only the net effect of numerous species performing individualistically is portrayed. Most species are to various degrees habitat generalists or their habitat requirements can be met by a combination of many habitat components. Not so the habitat specialists.

Fluvial Tall Shrubs and the Willow Flycatcher

Given the lack of relation between bird counts and revegetation age in SAs 1 and 2 (Fig. 6 and 7), it comes as no surprise that bird use in the main habitat type (fluvial tall shrubs) had similar bird counts over 16 years (Fig. 22). Each dot on the graph represents one station of specified age; each age usually has a different set of stations with variable overlap. (Note also the single extreme high count in the first year.)

Species richness, density, and equitability did in general increase with time in SAs 1 and 2 (Fig. 9-15). In the fluvial tall shrub type using data from all four subareas, species density showed no relating to age for eight years with a subsequent uptick (Fig. 23). For the 16-year period, age accounted for about $20 \%$ of the variance in species density in the fluvial shrub type. Data here indicate that it takes roughly nine years for willows to grow tall and dense enough to provide an important habitat for many bird species utilizing that vegetational structure.

The willow flycatcher (Empidonax traillii), generic relative of the endangered southwestern willow flycatcher (E. t. ssp. extimus), is entirely insectivorous, an aerial forager that captures its diet on the wing by darting out from elevated perches - mostly willows along the creek in the SSTOU, where summer insect hatches are common. These small flycatchers are one of the latest- 


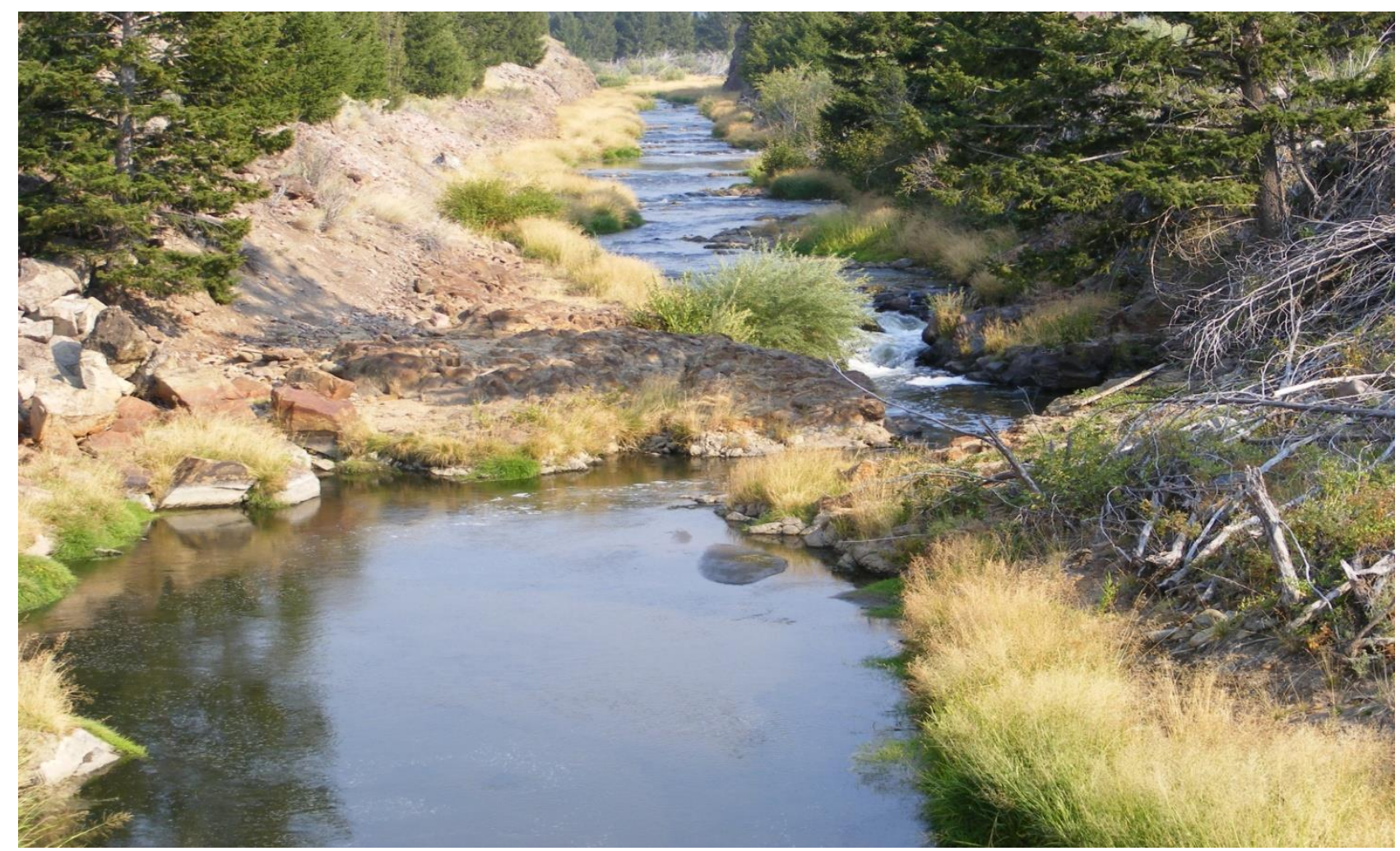

Figure 21. The canyon portion of this project required minimal remediation and retains mature vegetational structure; such sites were not used for habitat analysis.

\section{FIGURE 22. BIRD COUNTS IN THE FLUVIAL TALL SHRUB TYPE}

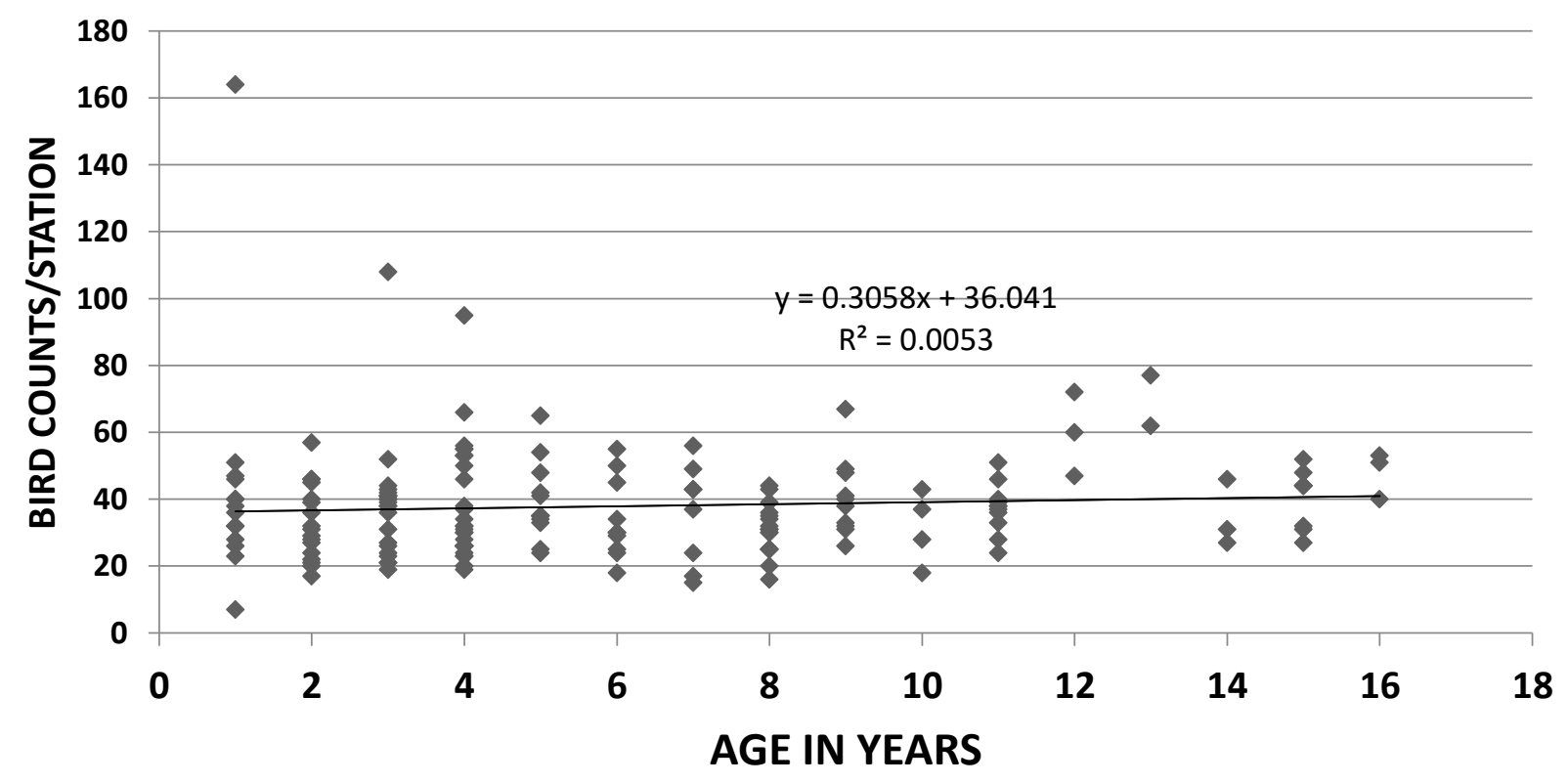




\section{FIGURE 23. SPECIES DENSITY IN THE FLUVIAL TALL SHRUB TYPE}

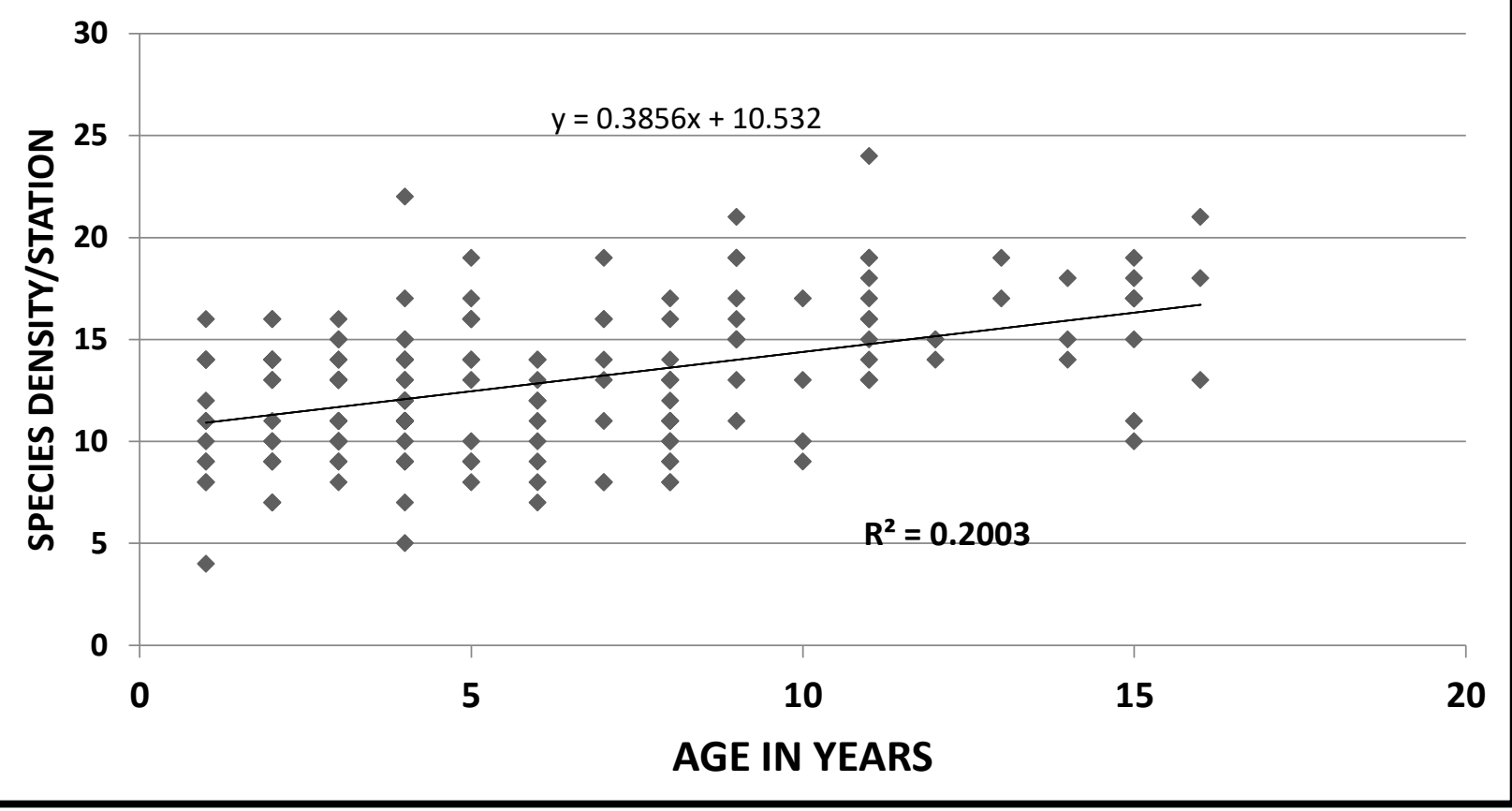

breeding passerines to arrive in the area, typically in the last few days of May, and occupy breeding territory during the June bird samplings. Nests are usually located 1-1.5 m above the ground in shrubs located near water. Abundant flying insects and tall riparian shrubs are the defining habitat components.

Our data from Subareas 1 and 2 indicate that willow flycatchers first appeared about six years after small willows were planted and increased in abundance thereafter. In the upper reaches of the more recently remediated Subarea 4, this species was found to begin use a little earlier - four years following revegetation. Two individuals were detected in June 2015 in the second reach (Reach Q), where the 2011 flood greatly enhanced willow spread and growth. The appearance of willow flycatcher is a classic indicator of woody plant development along a healthy stream with good invertebrate populations.

The following depicts June willow flycatcher counts in the two oldest subareas. Overlapping age ranges are unavoidable because subareas are remediated and revegetated over a sequence of years, so the set of reaches comprising a subarea varies in age. 


\begin{tabular}{cccc} 
& \multicolumn{3}{c}{ Willow Flycatcher } \\
& 6 AGE YEARS \\
& $6-10$ & $7-13$ & $11-17$ \\
& ----------- \\
& \multicolumn{3}{c}{ Bird Counts in June } \\
SA 1 & 2 & 14 & 18 \\
SA 2 & 2 & 9 & 12
\end{tabular}

Two more habitat specialists showing strong temporal trends are discussed next.

Wetlands and the Marsh Wren

Again, using data from all 80 stations, wetlands showed essentially flat bird counts over time amidst great variability (Fig. 24). Species density showed increasing trend similar to that of tall shrubs (Fig. 23), especially after year six with an outsize contribution to regression analysis from a single sample in year 16 (Fig. 25).

A habitat specialist that profits from developing emergent vegetation is the marsh wren (Cistothorus palustris). Fairly secretive, these wrens are more often heard than seen - males can be quite vocal during the breeding season. Their abundance tracks the succession of tall herbaceous plants such as cattails and bulrush and their spread in wetlands, but nearby shrubs can serve. Such relatively tall plants provide cover and nesting materials. Widespread and common, these small, active insectivores begin arriving regionally in late April becoming better represented in June. In 2016 in SA 2, three were counted in April, seven in May, and 10 in June.

The marsh wren first appeared in Subarea 2, the subarea with most wetlands, in 2014. At that time, two individuals were detected outside formal bird counts. Two years following, an obvious increase was noted: 10 individuals were detected at eight of 20 stations sampled during June. This increase in use occurred at around 10 years after initial seeding. As of 2017, cattails in Subarea 2 were still increasing, and with continued spread, marsh wren use is expected to increase.

\begin{tabular}{lcc} 
& \multicolumn{2}{c}{ Marsh Wren } \\
& COUNTS SA 2 \\
& 2014 & 2016 \\
APRIL & 0 & 3 \\
MAY & 0 & 7 \\
JUNE & 0 & 10
\end{tabular}




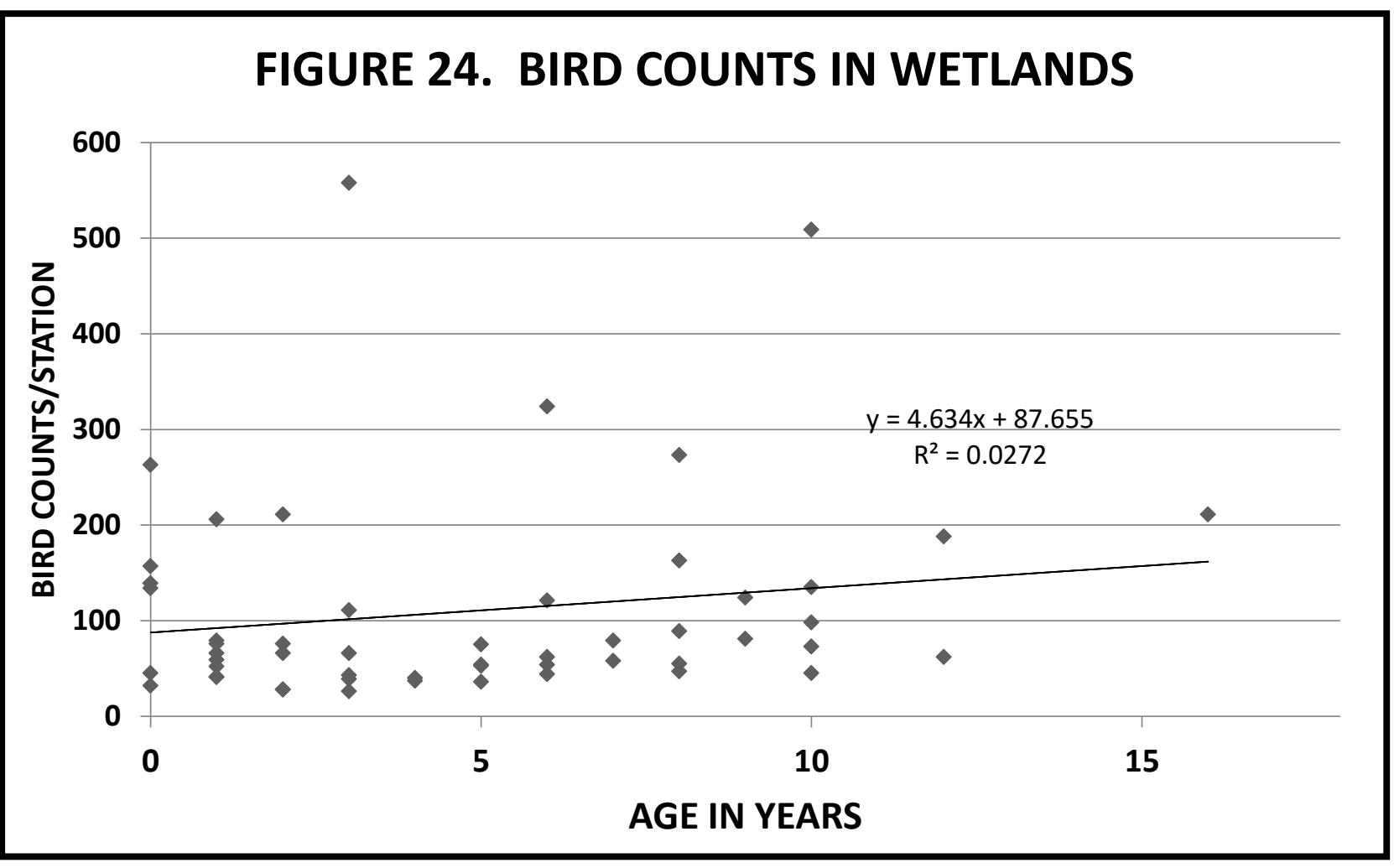

FIGURE 25. SPECIES DENSITY IN WETLANDS

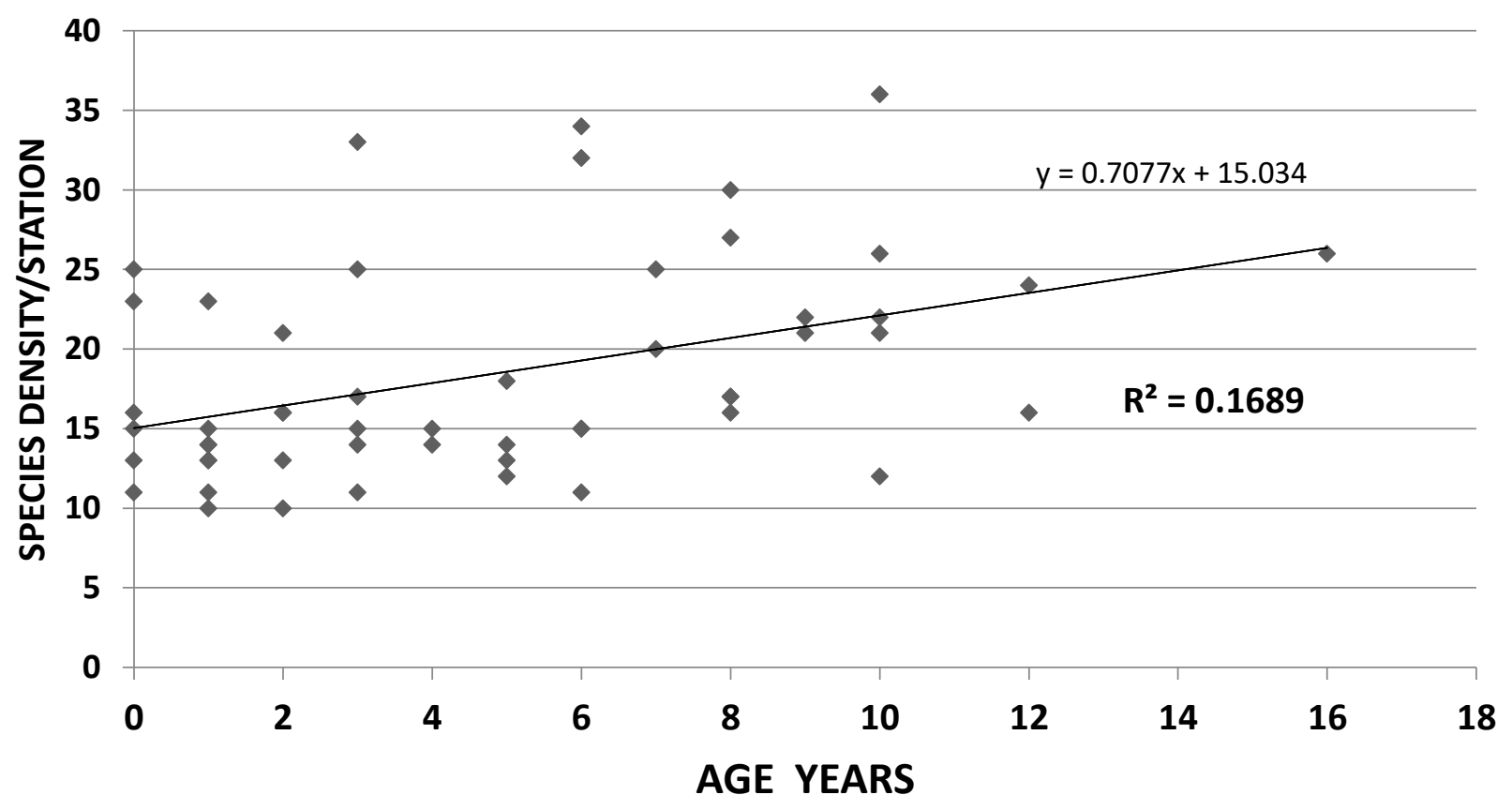




\section{Open Shores/Gravel Bars and the Spotted Sandpiper}

While healthy, diverse vegetation has always been the ultimate goal and of paramount importance to many bird species found within the remediated areas of Silver Bow Creek, the course of vegetational development can reduce the preferred habitat of some bird species, e.g., shorebirds. One example of this trend comes from another habitat specialist, the spotted sandpiper (Actitis macularius).

As soon as construction ended, spotted sandpipers began using streambanks and shorelines of newly constructed ponds. Widespread and locally common, this small sandpiper's habitat preference is open shoreline along streams, lakes, or ponds. They nest on open ground - typically sand or gravel bars - and forage for invertebrates at the water's edge. Arriving in the area around mid-May each year, spotted sandpipers are one of the most frequently seen breeding shorebirds encountered in May and June along Silver Bow Creek, but especially during the first few years following remediation.

In Subarea 4, which is second in ponds only to Subarea 2, sandpiper use immediately followed remediation. Remediation and revegetation in SA 4 was completed in 2014. Just one year later, the number of sandpipers observed declined $29 \%$.

\begin{tabular}{lcc} 
& \multicolumn{2}{c}{ COUNTS SA 4 } \\
& 2014 & 2015 \\
\cline { 2 - 3 } Individuals at 20 stations sampled in June & 38 & 27
\end{tabular}

The two oldest subareas showed sandpiper declines beginning just a few years after completion, although the upper reaches in each were by then a few years old. Subarea 2 has more ponds than SA 1 and a more ambiguous pattern. This is probably because slight changes in water elevations manifest large changes in exposed wet sediments, but diminished bird use remains unmistakable.

Spotted sandpiper counts from scheduled June sampling:

\begin{tabular}{ccccccccc} 
& & SA 1 & & \multicolumn{4}{c}{ SA 2 } \\
2005 & 2006 & 2010 & 2013 & 2017 & 2009 & 2012 & 2014 & 2016 \\
-17 & 13 & 4 & 4 & 4 & -14 & 28 & 6 & 14
\end{tabular}


Streambanks in Subareas 1 and 2 now have few sparsely vegetated gravel bars. Some open shoreline remains at a few of the ponds in Subarea 2, but those shores are filling with plants. In Subarea 4 below Durant Canyon, streambank characteristics differ; it's a wider stream with more flow that provides fresh gravel bars as the overly wide channel narrows. Due to the spring 20102011 floods, a fair amount of ideal spotted sandpiper habitat was recreated there through shiftingsediment deposition. Some still-contaminated wetlands remain essentially barren, and this too is sandpiper habitat. Spotted sandpipers are likely to remain more abundant in the lowest subarea than in the upper ones.

\section{SUMMARY}

Birds quickly colonize fresh revegetation in good numbers with no convincing temporal trend in the ensuing decade whether evaluated for subareas, habitat types, or tropic levels. Open water guarantees waterfowl and some other bird use as soon as construction is complete and more in the first year of revegetation. Bird species compositions are rather dissimilar among even consecutive years. Taken together, the cast changes but the net population dynamics remain about the same.

Species diversity combining richness (or species density) and evenness among standard samples showed an upward trend for the two oldest and most-sampled subareas. Species diversity increased while total bird use did not.

The big trends treat birds or species as interchangeable cogs in the analytic procedure. Habitat specialists evaluated individually show how important particular types of vegetational development can be to their presence and abundance.

\section{LITERATURE CITED}

MacArthur, R. 1964. Environmental factors affecting bird species diversity. American Naturalist 98: 387-397. https://doi.org/10.1086/282334

Recher, H.F. Bird species diversity and habitat diversity in Australia and North America. American Naturalist 103: 75-80. https://doi.org/10.1086/282583

Shannon, C.E. and W. Weaver. 1949. The mathematical theory of communication. Univ. of Illinois Press, Urbana.

Sorenson, T. 1948. A method of establishing groups of equal amplitude in plant sociology based on similarity of species content. Kong. Dan. Vidensk. Selsk. Biol. Skr. 2: 1-34. 
Thompson, L. 1980. Applications of the breeding-bird survey in baseline and monitoring studies. 21 pp. Presented at the Bird Census Symposium. Asilomar Ca. Oct. 27-31. https://doi.org/10.5962/bhl.title.69188

Whittaker, R. 1972. Evolution and measurement of species diversity. Taxon 21:213-251. https://doi.org/10.2307/1218190 